\title{
The missing link between granites and granitic pegmatites
}

\author{
Rainer THOMAS ${ }^{1 *}$, Paul DAVIDSON² \\ ${ }^{1}$ Helmholz Centre Potsdam, German Research Centre for Geoscience GFZ, Telegrafenberg, Potsdam, Germany; thomas@gfz-potsdam.de \\ ${ }^{2}$ ARC Centre of Excellence in Ore Deposits, University of Tasmania, Hobart 7001, Australia \\ * Corresponding author
}

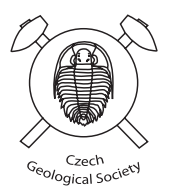

In this contribution we provide evidence for the extraction of volatile and incompatible element enriched melts from common granites. This provides a mechanism showing that at least a large proportion of granitic pegmatites could be genetically directly connected to a main granite body.

In granites there are often two principal types of melt inclusions: (i) those that represent the bulk chemistry of the granite and (ii) those with very different compositions. In the Variscan Erzgebirge granites, the second type is characterized by the abundance of fluorine. However, in other geodynamic settings inclusions in granites can contain high concentrations of other elements which may take over the function of fluorine.

From textural relationships the second inclusion type represents intergranular melts enriched in all elements incompatible with the ideal haplogranite system. Due to the high volatile content of such melts, the viscosity can be several orders of magnitude lower than the quasi-solid bulk system and can therefore move rapidly through the partially or totally crystallized host, and flow together into a separate system forming pegmatite bodies inside or outside the granite body. Another important effect of the high volatile content is the phase separation resulting from the speciation changes $\mathrm{OH}^{-} \rightarrow \mathrm{H}_{2} \mathrm{O}$ or $\mathrm{CO}_{3}{ }^{2-} \rightarrow \mathrm{CO}_{2}$ due to temperature and/or pressure changes at different locations within the granite-intergranular melt system. Since melt inclusions provide a means of conserving original un-degassed compositions, they yield important evidence for closing the gap between granites and granitic pegmatites.

The paper is dedicated to two Czech colleagues - Petr Černý and Milan Novák - who have devoted their lives to the study of granitic pegmatites.

Keywords: granites, pegmatites, melt inclusions, intergranular melts, $F_{-}, P_{-}$, and $B$-rich melts

Received: 17 January 2013; accepted: 26 May 2013; handling editor: P. Uher

\section{Introduction}

Research into the nature and origin of pegmatites has been ongoing for more than a century, and comprehensive accounts of the historical developments were given by Schneiderhöhn (1961) and London (2008). Likewise Thomas et al. (2012b) discussed the competing models for the origin and internal evolution of granitic pegmatites in the light of melt and fluid inclusion research. Typical studies of pegmatites have begun with the emplacement of the pegmatite into its host rock; however, this leaves unanswered the general question of when and how pegmatites or more evolved melts are derived from their source granites (London and Morgan 2012).

This is a very important point, since the answer may change the accepted picture. The chain of evidence needs to start at the very beginning and not in the middle nor at the end of the process. Although many pegmatites contain high concentrations of rare elements, it should be noted that the majority of pegmatites are of the simple quartzfeldspar \pm muscovite type, so any answer must apply to both simple and complex pegmatites.

In this paper we interpret fluid and melt inclusions which represent the compositions of the fluid and melt phases present at the final stages of the crystallization of granites, but generally before the formation of pegmatites. The reconstruction of these records is a very important task for any experimentalists studying geological processes, since ignoring these leads may risk incorrectly constraining the problem of how pegmatite-forming melts can be extracted from cooling granite, and what effect this must have on their compositions.

\section{Melt extraction - the granite-pegmatite link}

The problem of the extraction of pegmatite melts has been pointed out by McKenzie (1985), who wrote that "the ability of a melt to separate from the residual crystals depends principally on the viscosity of the melt" and further "acid melts will only be able to move with respect to their matrices if their viscosity is less than about $10^{2} \mathrm{~Pa} . \mathrm{s}$, a condition which is only likely to be satisfied if the melts are very rich in volatiles". Although this value need not be an absolute number, we will argue that it is in the right order of magnitude (Thomas and Webster 2000). 
Important evidence for the low viscosity of pegmatiteforming systems is provided by hydrothermal diamond anvil cell (HDAC) experiments (Veksler et al. 2002; Audétat and Keppler 2004). Measurements of the different phases in the experiments performed by Veksler at al. (2002) demonstrated an unusually high solubility of the aluminosilicate components in the fluid at high temperatures: at $830^{\circ} \mathrm{C}$ there is about 26 melt $\%(\mathrm{~g} / \mathrm{g})$ dissolved in the fluid (fluid density 0.5 and melt density $2.0 \mathrm{~g} / \mathrm{cm}^{3}$ respectively) - see also fig. 7 in Thomas et al. (2006). The viscosity is very low, as shown by the rapid movement of small particles, and the diffusivity of all components is very high, indicated by the very rapid adjustment of the melt volumes with temperature changes. In addition, from this experiment it follows that the vapor formation is suppressed until a very late stage at low temperatures $\left(300^{\circ} \mathrm{C}\right)$. Such behavior prevents the rapid "viscous death" (Pistone et al. 2013) of the residual melt.

A further prerequisite is that the melt must be able to form stable three-dimensional interconnected networks, because extraction and separation of disconnected melts pockets from the crystalline framework is extremely difficult.

Since the pioneering work of Goranson (1931) and Tuttle and Bowen (1958), countless experiments in the system granite- $\mathrm{H}_{2} \mathrm{O}$ have been performed, and have given us much new data concerning properties of melts and magmas, mechanism of dehydration melting, and phase relationships mostly under $\mathrm{H}_{2} \mathrm{O}$-undersaturated conditions (Johannes and Holtz 1996). There are several models for the estimation of felsic melt viscosity, starting with the empirical approach based on compilations of experimental results presented by Shaw (1972) and the improved model by Giordano et al. (2008). Recently Bartels et al. (2013) studied the effect of fluorine, boron and phosphorus on the viscosity of pegmatite-forming melts. However, in this work the known facts obtained from new experiments (e.g., Audétat and Keppler 2004), and especially the data and facts obtained from the study of melt inclusions, are completely ignored. Thus low $\mathrm{H}_{2} \mathrm{O}$ concentrations are assumed, which is consistent with the London model $(2008,2009)$, but in our view this compromises their results.

Melt volatiles are fugitive, and with increasing volatile concentrations even more so. Their loss by degassing is essentially inevitable and moreover leaves little if any trace. Thus, primary melt and fluid inclusions trapped in magmatic minerals during magma crystallization provide almost the only method of estimating true original melt volatile concentrations. Melt and fluid studies are not without their difficulties, as is the interpretation of their results (for example see Roedder 1984; Lowenstern 1995), but these techniques are very rarely taken into account by the experimental petrologists (e.g., Johannes and Holtz 1996; London 2008; Bartels et al. 2011, 2013).

Thus, nearly all these important and necessary studies consider the system granite- $\mathrm{H}_{2} \mathrm{O}$ more or less as closed and stationary "ideal" systems, although a few papers also discuss the evolutionary path of rising granite magmas into the upper crust (e.g., Sykes and Holloway 1987; Clemens and Droop 1998). In part the problem is also due to the way the experiments are carried out, magmatic evolution is generally excluded from the discussion, or only mentioned at the very beginning or more generalized as a physicochemical model. It is almost impossible to represent the evolution of melts from parental granite magma to a pegmatite in this type of equilibrium experiments; nature does not work in such a simplified manner. Therefore typical experiments represent only single points in pegmatite evolution. What we need is a large series of experiments representing the whole evolution. Moreover, most single steps are, or can be, masked by subsequent sub-solidus processes. However, nature conserves snapshots of the natural processes as fluid and melt inclusions; we have only to decipher the records. Although melt inclusions show clearly that the residual melt state was an important step during the evolution of many granites, experimental petrologists have performed experiments without feedback from the melt inclusions which are important testimonies to past processes.

Since most authors take the view that pegmatite magma originates in granitic one, it follows that any search for the origin of pegmatites should begin by assessing the potential of granites as pegmatite precursors. Moreover, granites need to be examined not only for their potential, but also for evidence of the mechanisms by which the pegmatites magmas were derived from those parental granites.

\section{Melt inclusions in granitic rocks}

As a rule most melt inclusions (MI) in intrusive rocks are usually very small, typically less than $10 \mu \mathrm{m}$ across. With only rare exceptions the included material has completely re-crystallized, often with a well-formed aqueous droplet with a vapor bubble, due to the slow cooling. The ratio between this bubble and solid material of the inclusion depends on the bulk water content, the bulk density, the trapping temperature and pressure, as well as the cooling rate.

For analytical purposes, the melt inclusions in granitic and pegmatitic rocks have to be re-homogenized at higher pressure (to prevent decrepitation and volatile loss) and higher temperatures to form a homogeneous glass. This is not a simple task, because over- or under-heating must be prevented. It should be pointed out however, that MI in 
volcanic rocks also may need re-homogenization to deal with post-trapping crystallization of daughter crystals, bubble formation, and epitaxial crystallization of the host mineral on the inclusion walls. Even in clear glass inclusions in volcanic rocks failure to re-homogenize may miss significant material from the analysis.

Melt inclusions in minerals of granitic rocks have long been studied; in particular we note the exemplary work of Naumov (1979), Thomas (1979, 1994), Frezzotti (1992), Student (2002) and several papers in the Canadian short course volume edited by Webster (2006). Four points in such studies are of primary importance: (i) that such melt inclusions exist, allowing investigation of un-degassed melt compositions, (ii) the bulk composition of the melt inclusions may mirror the magma composition, in particular (iii) their water content, and (iv) trace-element concentrations.

As a first approximation we can consider that the major-element bulk composition of most uncompromised melt inclusions in granites is similar to that of the host rock. This is true especially for the early trapped melt inclusions along growth zones. Greater deviations occur in the water content and in the trace-element inventory. As a rule the water content of the bulk rock is not identical to that of the magma, since water is inherently fugitive. Furthermore we will show that there is a significant minority of melt inclusions with compositions which differ considerably from the bulk rock, especially in the water concentration as well as in the alkalis and in some cases in $\mathrm{P}, \mathrm{B}$, or $\mathrm{F}$. The contents of the last element can increase up to $12 \%(\mathrm{~g} / \mathrm{g})$ - far from a normal granitic rock.

In a review paper Thomas and Davidson (2012a) compiled the water contents of melt inclusions in minerals of granites and pegmatites. Generally, the water concentration in granite melts representing a large number of granites is $<10 \%(\mathrm{~g} / \mathrm{g})$ with three maxima at $4.0 \pm$ $1.3,5.9 \pm 1.2$, and $8.1 \pm 1.1 \%(\mathrm{~g} / \mathrm{g})$. However, we found rare inclusions with significantly higher $\mathrm{H}_{2} \mathrm{O}$ concentrations; values typical of pegmatites were reported from most intrusive granites, for example the highly evolved porphyritic topaz-albite-zinnwaldite microgranite dike at Zinnwald (see Thomas and Davidson 2012a, page 39), in the Greifenstein granite (both in the Erzgebirge, Germany), or in the Pliocene Eldzhurtinskiy I-type biotite granite (Caucasus, Russia) - see Fig. 1. In the last example several large isolated melt inclusions were observed in quartz with $16.5 \%(\mathrm{~g} / \mathrm{g})$ and some inclusions which homogenize by critical behavior, with up to $31 \%(\mathrm{~g} / \mathrm{g})$ bulk water after re-homogenization at $750^{\circ} \mathrm{C}$ and $3 \mathrm{kbar}$ using the cold-seal pressure vessel technique. These inclusions resemble rare melt inclusions in peralkaline rhyolites from the Pantelleria Island, Italy, described by Naumov et al. (1987). Further examples of granites with "abnormally" high water concentration in the melt
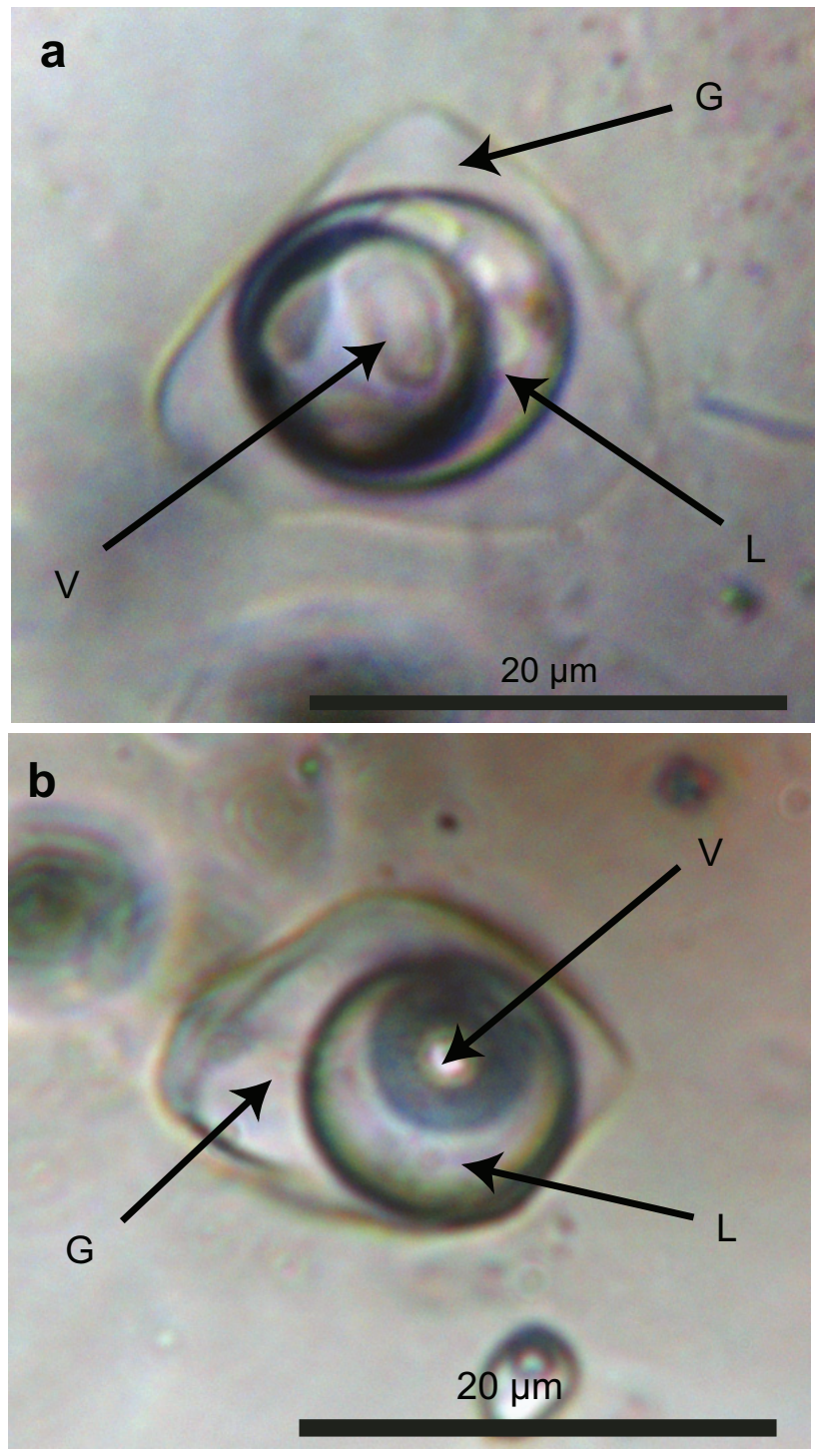

Fig. 1a - Water-rich type-B melt inclusions in granite quartz: a - Greifenstein granite, Central Erzgebirge, Germany - re-homogenized at $650^{\circ} \mathrm{C}$ and $1 \mathrm{kbar} ; \mathbf{b}-$ in the Pliocene Eldzhurtinskiy I-type biotite granite (Caucasus, Russia) re-homogenized at $750^{\circ} \mathrm{C}$ and $3 \mathrm{kbar}$. $\mathrm{G}-$ glass, $\mathrm{L}$ - aqueous liquid, $\mathrm{V}$ - vapor phase.

inclusions were found in the Precambrian Kymi granite, Finland (Lukkari et al. 2009) and in the Lake Lewis Leucogranite in the South Mountain Batholith, Nova Scotia, Canada (Clarke and Bogutyn 2003). The last example is interesting, because the primary melt inclusions in the granite quartz were generally partially decrepitated during the structural uplift on the way to the intrusion level. Only the youngest melt batches are conserved as inclusions in topaz crystals, showing that this inclusion type was trapped at a very late state of the magmatic evolution. Some of these inclusions are relatively large and can be viewed as representing micro-pegmatite systems (Fig. 2). 


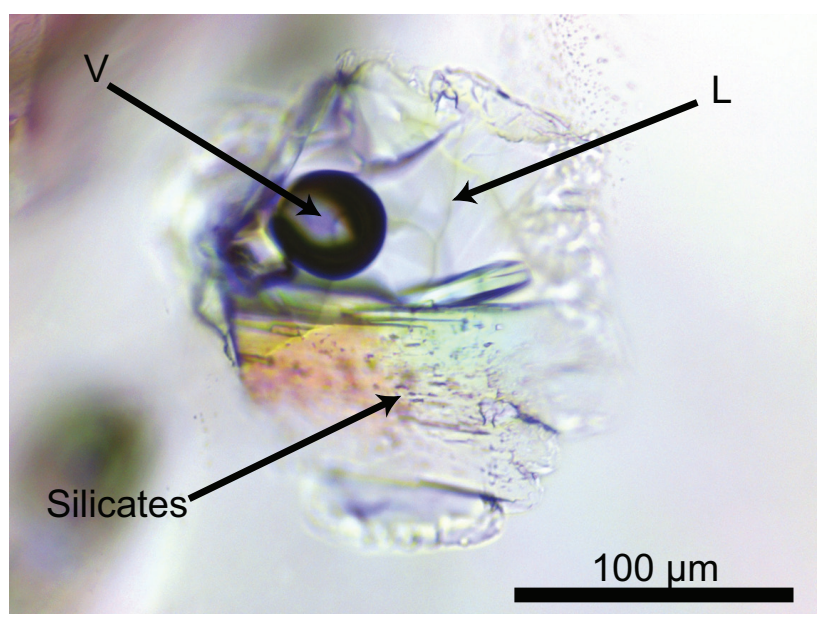

Fig. 2 Large water-rich melt inclusion in topaz of the Lake Lewis leucogranite in the South Mountain Batholith in Nova Scotia, Canada. The inclusion can be viewed as "micropegmatite". L - solution, V - vapor bubble, Silicates - mostly micas, feldspars and quartz.

The frequency of these characteristically "anomalous" melt inclusions generally increases with the abundance of pegmatites associated with the granite. In granites without any pegmatites, e.g. Eldzhurtinskiy I-type biotite granite (Caucasus, Russia), such inclusions are relatively rare and can be easily overlooked. In granites with related pegmatites, e.g. Ehrenfriedersdorf, Geyer, Eibenstock, Kymi, and Malkhan, the ratio of granite-related and intergranular-related melt inclusions is about $1: 1$. In the extreme case there are granites such as the porphyritic topaz-albite-zinnwaldite microgranite dikes from Zinnwald, in which the typical granite melt inclusions are rare but the water- and volatile-rich ones are extremely abundant. We have interpreted such cases as having had too many crystallization nuclei for a normal pegmatite to form (Thomas et al. 2005), and which can be considered in a sense as embryonic pegmatites.

In many granites of the Erzgebirge region, which are related to the Variscan $\mathrm{Sn}-\mathrm{W}$ mineralization, there are late-stage topaz crystals containing melt inclusions together with primary syngenetic fluid inclusions, demonstrating high water and fluorine concentrations at the end of the granite-related magmatism as intergranular melts. Because many scientists working with evolved granites are unfamiliar with the world of fluid and melt inclusions, in the past these topaz crystals were often regarded as postmagmatic, forming during the greisenization stage (Ossenkopf and Helbig 1975; Weinhold 2002), which generally is characterized by low-density fluid inclusions. However, the melt inclusions in this topaz demonstrate clearly the existence of highly mobile, water and fluorine-rich melts moving along grain boundaries at more or less equilibrium conditions due to their low density and viscosity during compaction of the bulk system (see also fig. 35 in Kovalenko and Kovalenko
1976). A sudden pressure decline, triggered by tectonic movements, can cause that this melt-dominated system can swap over into a vapor-dominated greisen system. Other granites in the region, not related to the $\mathrm{Sn}-\mathrm{W}$ deposits, contain only very rare indications of such mobile interstitial melts. In these cases we would suggest that the primary porosity was not interconnected, and was closed during the late phase of crystallization similar to the case described by Bryon et al. (1996). As an example the Kirchberg granite, West-Erzgebirge, Germany, which for the last 70 years has been viewed as an early separate stage of the Variscan granites (Tischendorf 1989), contains rare, mostly isolated, very fluorine-rich melt inclusions and also F-rich minerals (e.g., cuspidine $\left[\mathrm{Ca}_{4} \mathrm{Si}_{2} \mathrm{O}_{7}(\mathrm{~F}, \mathrm{OH})_{2}\right]$ and fluorite), which up to now were ignored. However, sometimes there are also decimetersized magmatic segregations in these simple granites with F-enriched melt inclusions $(1.45 \%(\mathrm{~g} / \mathrm{g})$ versus $0.2 \%$ in primary MI of the bulk rock). Furthermore, in earlier papers (e.g. Thomas et al. 2005) we have demonstrated that in clearly peraluminous granites there are typically remnants of a peralkaline state. As an example the unambiguously peraluminous porphyritic topazalbite-zinnwaldite microgranite dike from Zinnwald is characterized by small cryolite and rare Rb-leucite crystals (Thomas et al. 2005), which are clear indications of a separate short evolutionary path within the overall peraluminous bulk development.

During granite crystallization the formation of isolated melt pockets and/or of interconnected melt systems are possible. Which of these occurs depends on the porosity of the crystal mush and the primary composition of the magma, in the simplest case on the water concentration of the melt and on the type of the source. Most pegmatites are related to S-type (sedimentary source) and A-type granites (Černý et al. 2012). According to these authors the latter type is related to an anorogenic environment,

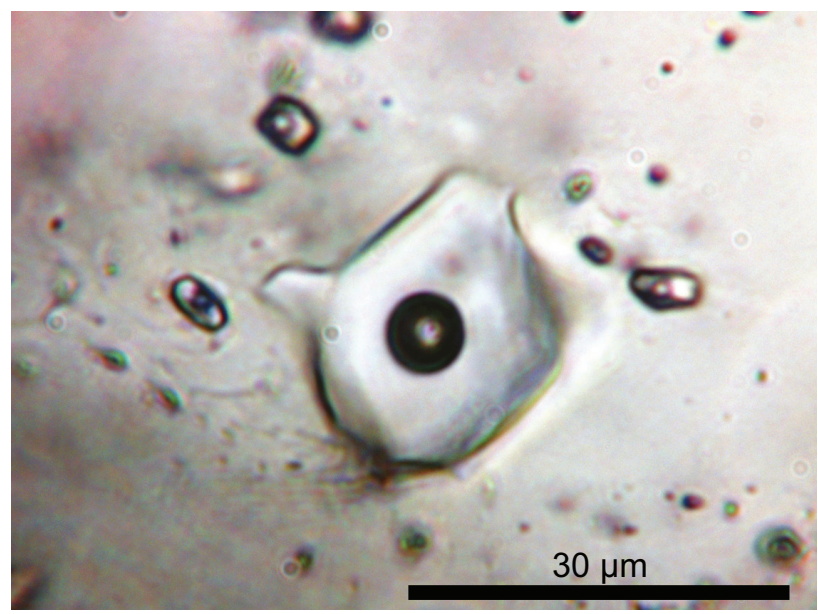

Fig. 3 An isolated melt inclusion (re-homogenized at $700{ }^{\circ} \mathrm{C}$ and $3 \mathrm{kbar}$ ) in quartz of an aplite from the Königshain granite, see text for details. 

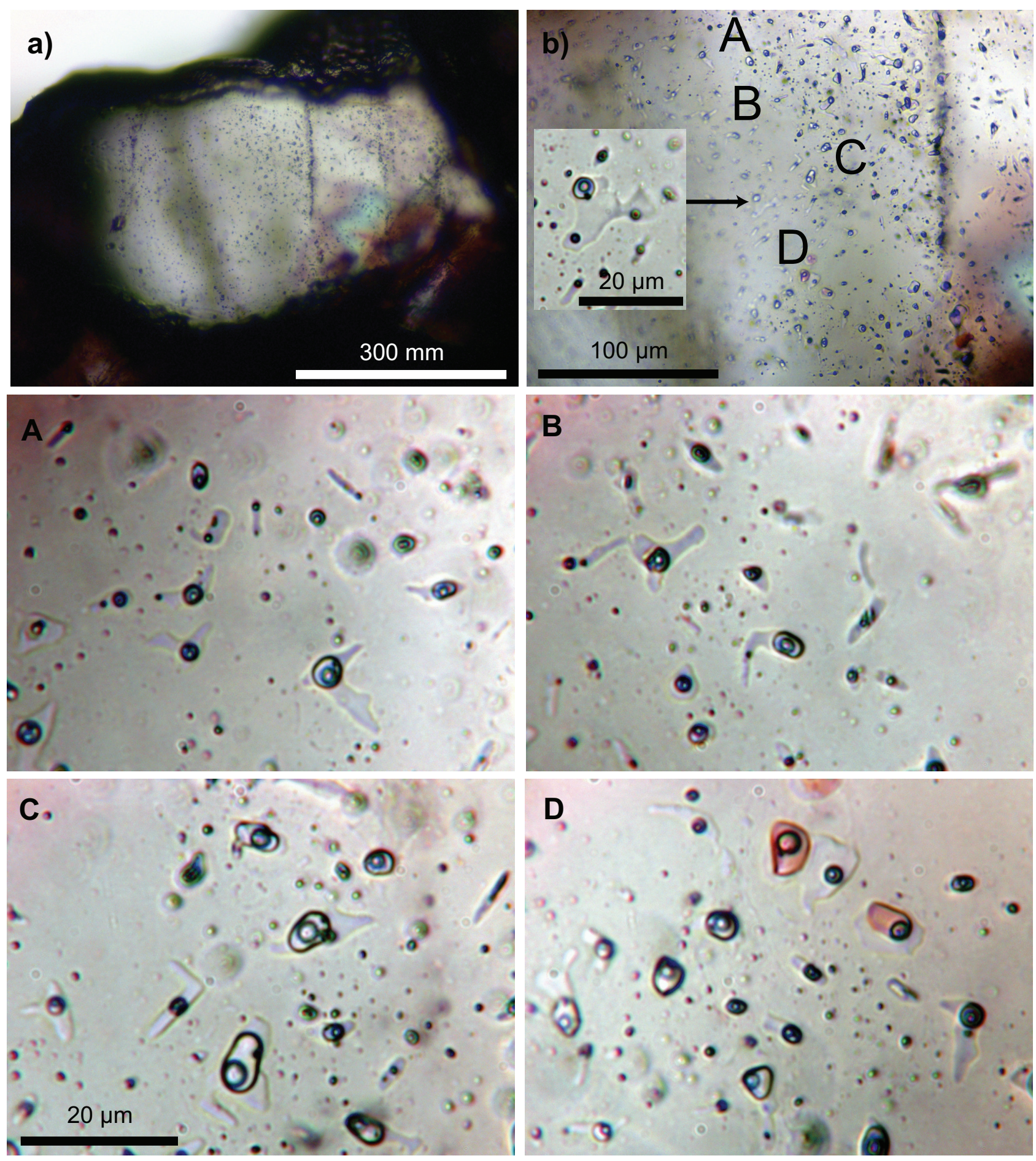

Fig. 4a - A quartz grain in the Königshain aplite (rehomogenized at $700^{\circ} \mathrm{C}$ and $3 \mathrm{kbar}$ ) filled with innumerable melt inclusions in a growth zone. b - shows details of such growth zone. The insert is a single melt inclusion with type-A characteristics. A-D are enlargements of the same regions in Fig. 4b. All visible inclusions are melt inclusions with different degree of filling.

lower continental crust \pm mantle source. As a rule, the composition of the sedimentary protolith is far from the eutectic minimum of any granite. Given the change in pressure and temperature between the magma source and intrusions depths, the composition of the primary melt would be very different from that at intrusion level. Due to partitioning behavior all components which are incompatible with the idealized "granite system" in the relevant $\mathrm{P}-\mathrm{T}$ framework, will be sequestered en route from the source to the place of intrusion. The underlying process 
is the general chemical evolution of magmatic melts with time and decreasing temperature (Thomas 1979, 1982, 1990; Reyf 1990, 2009; Johannes and Holtz 1996).

Due to the crystallization of the anhydrous minerals (feldspars and quartz) the resulting residual melt will be further enriched in water and all elements which are incompatible with the Qtz- $\mathrm{Ab}-\mathrm{Or}-\mathrm{H}_{2} \mathrm{O}$ system. Only small amounts of water and fluorine, as examples, will be consumed by the crystallization of micas, mostly at a late stage. If the crystal-melt system reaches a textural equilibrium at a large porosity $(>20 \%)$ the channels are relatively large and open in all cases (Cheadle et al. 2004). At a high water concentration and at magmatic temperatures such residual melts have viscosities $\leq 100$ Pa.s (Thomas and Webster 2000) and as such are highly mobile.
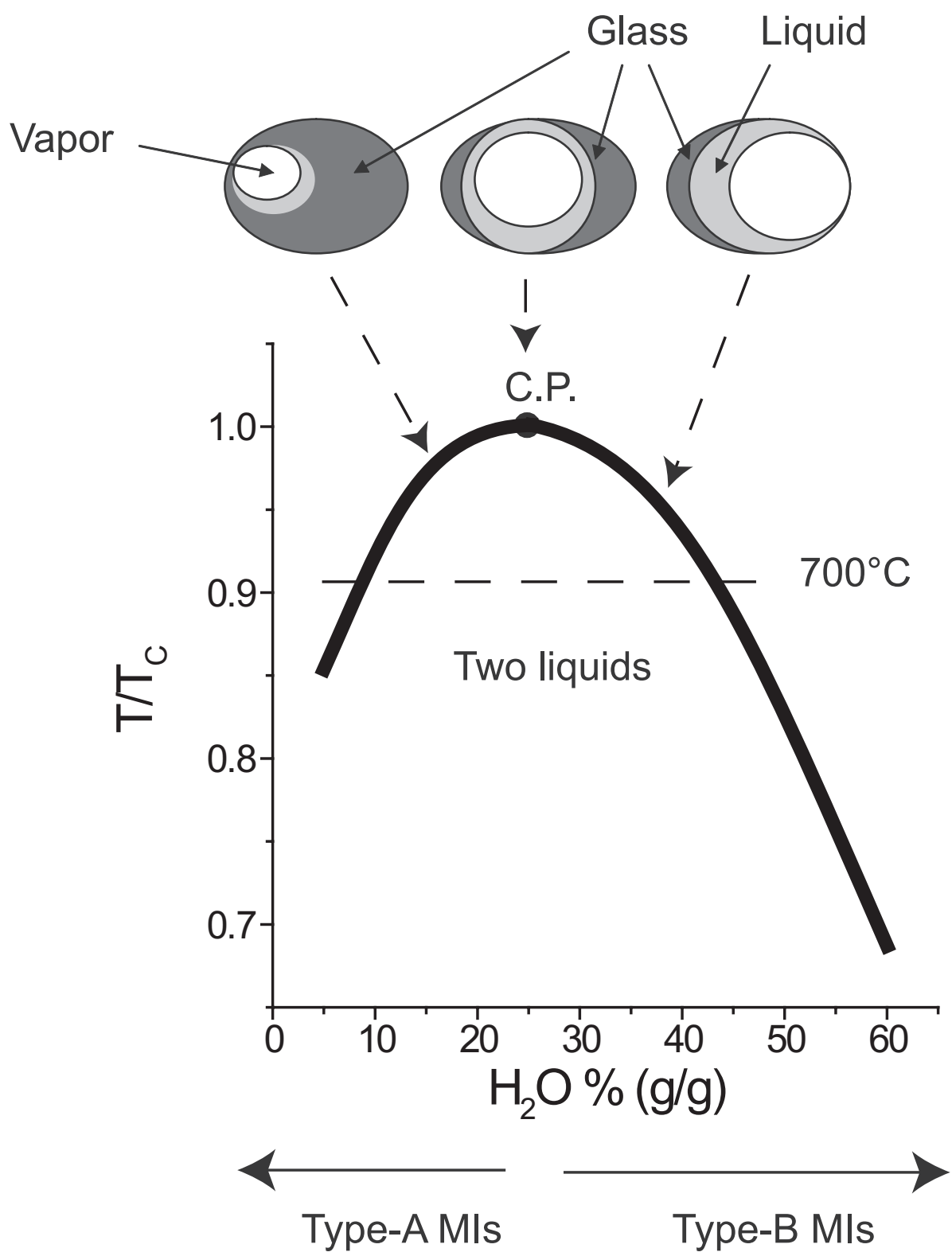

An excellent example of the enrichment of water by rapid crystallization of mainly quartz and feldspars is the fine-grained aplite zone of miarolitic cavities in the Königshain granite, eastern Germany. The approximately $3.5 \mathrm{~cm}$ wide aplite zone is separated from the granite by a cryptocrystalline quartz-feldspar zone c. $2 \mathrm{~mm}$ thick. Quartz from the aplite contains isolated melt inclusions (Fig. 3) of primary character with a water content of 7.9 $\pm 0.7 \%$ (g/g), marginally more than the granite magma. In some quartz crystals there are growth zones containing many small melt inclusions, some with very high water contents (Fig. 4a-b and enlargements A-D in Fig. 4b). The water content is highly variable, between 8 and $50 \%$ ( $\mathrm{g} / \mathrm{g}) \mathrm{H}_{2} \mathrm{O}$. As such, they may be considered as residual melts and fluids, but they cover the gap between normal silicate melts with less than $8 \%(\mathrm{~g} / \mathrm{g})$ water, and typical residual fluids with more than $90 \%$ water. Such growth zones look like a "cross-section" through the pseudobinary solvus curve at constant temperature, here $700{ }^{\circ} \mathrm{C}$ at 3 kbar (Fig. 5). Note that in this diagram the reduced temperature $\mathrm{T} / \mathrm{T}_{\mathrm{C}}$ is used, where the actual temperature and critical temperature are expressed on

Fig. 5 Relationship of type-A and B melt inclusions (MI) in a reduced temperature $\mathrm{T} / \mathrm{T}_{\mathrm{C}}$ vs. $\mathrm{H}_{2} \mathrm{O}$ concentration plot of the pseudo-binary system silicate melt $-\mathrm{H}_{2} \mathrm{O}$ for the aplite case. $\mathrm{T}$ is the run and $\mathrm{T}_{\mathrm{C}}$ is the critical temperature (in $\mathrm{K}$ ), respectively. C.P. is the critical point - here $800^{\circ} \mathrm{C}$. The dotted line through the boundary curves at $700^{\circ} \mathrm{C}$ (3 kbar) represents the "cross-section" of the quenched re-homogenization experiment. Melt inclusions trapped at the boundary conditions are homogeneous in composition and represent the extreme cases regarding the water concentration. All inclusions inside the boundary curves are strongly heterogeneous in composition. The pseudo-binary solvus curve is based on a large number of studied melt inclusions in granites, aplites, pegmatites worldwide. Inclusion types are discussed in detail in section 4.0.

In its upper part, this figure schematically shows three different types of melt inclusions (type-A, near critical, and type-B) at room temperature, after re-homogenization, containing glass, a water-rich liquid phase, and a vapor bubble. The appearance of the individual inclusion types is independent of the rock type. 


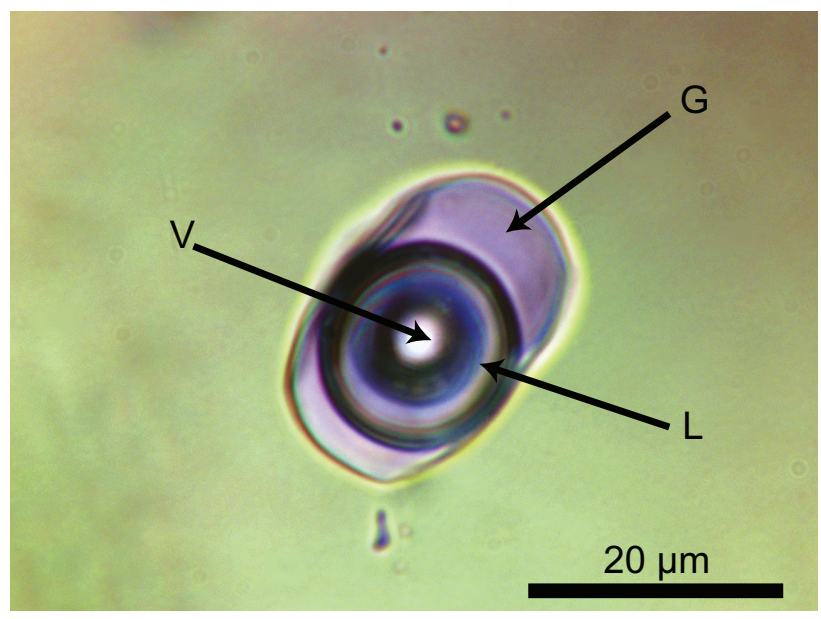

Fig. 6 Isolated water-rich type-B melt inclusion in quartz of the Kirchberg granite (Ki 305) after re-homogenization at $750^{\circ} \mathrm{C}, 3 \mathrm{kbar}$ at 20 hours using the cold-seal pressure vessel technique (Thomas et al. 2009b). G - silicate glass, $\mathrm{L}$ - water-rich solution, $\mathrm{V}$ - vapor $\left(\mathrm{CO}_{2}\right.$ and other gas components are below Raman spectroscopy detection limits).

absolute temperature scales. This procedure permits different homogenization experiments around the critical temperature to be better compared.

Such water-rich melt has a low viscosity and can move rapidly in the direction of any pressure gradient, in this case the opening miarolitic cavities. The aplitic zone passes directly and sharply into the graphic granite zone. Melt inclusions in quartz in this zone contain $18.4 \%$ (g/g) $\mathrm{H}_{2} \mathrm{O}$ (Thomas et al. 2009b).

This scenario can be found in many, and perhaps most granites, as a logical and necessary consequence of the enrichment in water and other volatiles during crystallization of the nominally water-free minerals quartz and feldspar along the grain boundaries. Even in the Variscan Kirchberg granite in the western Erzgebirge, which is not related to $\mathrm{Sn}-\mathrm{W}$ mineralization, such water-rich inclusions can be found (Fig. 6).

Here we would emphasize that although a suitable composition for the mobile melts is a prerequisite, it is not alone sufficient for the pegmatite formation. Pressure and temperature conditions as well as the abundance of crystallization nuclei are further important conditions. There are some analogies between the evolution to pegmatites or to highly evolved granites or apogranites (Syritso 2002; Letnikov 2008 and references therein).

Although water concentration in silicate melts has a strong effect on viscosity, other elements may have similar effects. We will begin by confining our attention to the water and fluorine contents of the granite- and pegmatiteforming melts and we will see that sometimes the composition of some granite melt fractions can significantly differ from the bulk-rock compositions. However, in other systems elements and compounds other than fluorine may serve similar purposes, and these will be considered later.

\subsection{Fluorine content of melt inclusions}

During the analytical study of melt inclusions in minerals of granitic rocks using microprobe techniques, fluorine is routinely determined. Beside the effect of $\mathrm{F}$ on reducing the liquidus and solidus temperatures, and increasing the size of the primary stability field of quartz, $F$ also causes an increase in the solubility of water in the granitic melts (Johannes and Holtz 1996). According to Naumov et al. (2000) acidic magmatic melt (> $\left.63 \%(\mathrm{~g} / \mathrm{g}) \mathrm{SiO}_{2}\right)$ in various geodynamic settings contains $0.60 \pm 0.24 \%$ (g/g) F $(\mathrm{n}=788)$.

During microprobe studies of melt inclusions in quartz of the Variscan Erzgebirge granites and pegmatites, unusual fluorine-rich melt inclusions were found in both rock types. Values up to $12 \%(\mathrm{~g} / \mathrm{g})$ were measured. The $\mathrm{F}$ concentration of 2070 melt inclusions in quartz from various Variscan granites and pegmatites from the Erzgebirge region are plotted as histograms in Fig. 7a-b. Typical data on the composition of the bulk rock and intergranular melt inclusions are given in Tab. 1.

Generally granites and pegmatites related to the $\mathrm{Sn}-\mathrm{W}$ deposits of the Erzgebirge region are very F-rich rocks (Fig. 8 and Tab. 2). Extreme values occur in the pycnite rock forming the stockscheider of some granites (Altenberg, Zinnwald and Sadisdorf) or the Schneckenstein topaz breccias in the western part of the Erzgebirge region. Table 2 gives the bulk composition of the pycnite rock from Altenberg according to Recknagel (1969) and Wein-

Tab. 1 Compositions of typical intergranular melt inclusions in quartz of the Greifenstein granite, Central Erzgebirge, Germany (re-calculated on water-free basis)

\begin{tabular}{lccc}
\hline & Bulk-rock $^{1}$ & Inclusion 1 (E7) & Inclusion 2 (E2) \\
\hline $\mathrm{SiO}_{2}$ & 70.90 & $68.90 \pm 0.44$ & $69.79 \pm 0.73$ \\
$\mathrm{TiO}_{2}$ & 0.10 & $0.09 \pm 0.02$ & $0.18 \pm 0.02$ \\
$\mathrm{Al}_{2} \mathrm{O}_{3}$ & 15.90 & $13.45 \pm 0.25$ & $13.18 \pm 0.48$ \\
$\mathrm{~B}_{2} \mathrm{O}_{3}$ & n.d. & 0.06 & 0.05 \\
$\mathrm{FeO}$ & 1.06 & $2.77 \pm 0.18$ & $3.78 \pm 0.10$ \\
$\mathrm{MnO}$ & 0.03 & $0.28 \pm 0.03$ & $0.05 \pm 0.02$ \\
$\mathrm{MgO}$ & d.1. & $0.03 \pm 0.01$ & $0.15 \pm 0.02$ \\
$\mathrm{CaO}$ & 0.75 & $0.39 \pm 0.03$ & $0.10 \pm 0.01$ \\
$\mathrm{Li}_{2} \mathrm{O}$ & 0.13 & $0.70 \pm 0.09^{2}$ & $0.95 \pm 0.12^{2}$ \\
$\mathrm{Na}_{2} \mathrm{O}$ & 4.90 & $2.20 \pm 0.08$ & $3.25 \pm 0.21$ \\
$\mathrm{~K}_{2} \mathrm{O}$ & 4.10 & $5.43 \pm 0.24$ & $4.66 \pm 0.12$ \\
$\mathrm{Rb}_{2} \mathrm{O}$ & 0.21 & $0.57 \pm 0.01$ & $0.50 \pm 0.03$ \\
$\mathrm{Cs}_{2} \mathrm{O}$ & n.d. & $0.04 \pm 0.01$ & $0.06 \pm 0.01$ \\
$\mathrm{~F}$ & 0.66 & $5.15 \pm 0.08$ & $3.10 \pm 0.14$ \\
$\mathrm{Cl}$ & n.d. & $0.02 \pm 0.01$ & $0.01 \pm 0.01$ \\
$\mathrm{P}_{2} \mathrm{O}_{5}$ & 0.66 & $0.26 \pm 0.13$ & $0.17 \pm 0.02$ \\
\hline $\mathrm{Sum}_{\mathrm{Dimension}}$ & 99.40 & 100.34 & 99.98 \\
$\mathrm{ASI}$ & 1.10 & $115 \mu \mathrm{m}$ & up to $200 \mu \mathrm{m}$ \\
\hline $\mathrm{acc}$ & & & $0.93 \pm 0.22$ \\
\hline
\end{tabular}

${ }^{1}$ according to Hösel (1994)

${ }^{2}$ determined by NIR femtosecond LA-ICP-MS (Borisova et al. 2012)

d.1. - detection limit, n.d. - not determined 


\section{(a) Melt inclusions in granites}

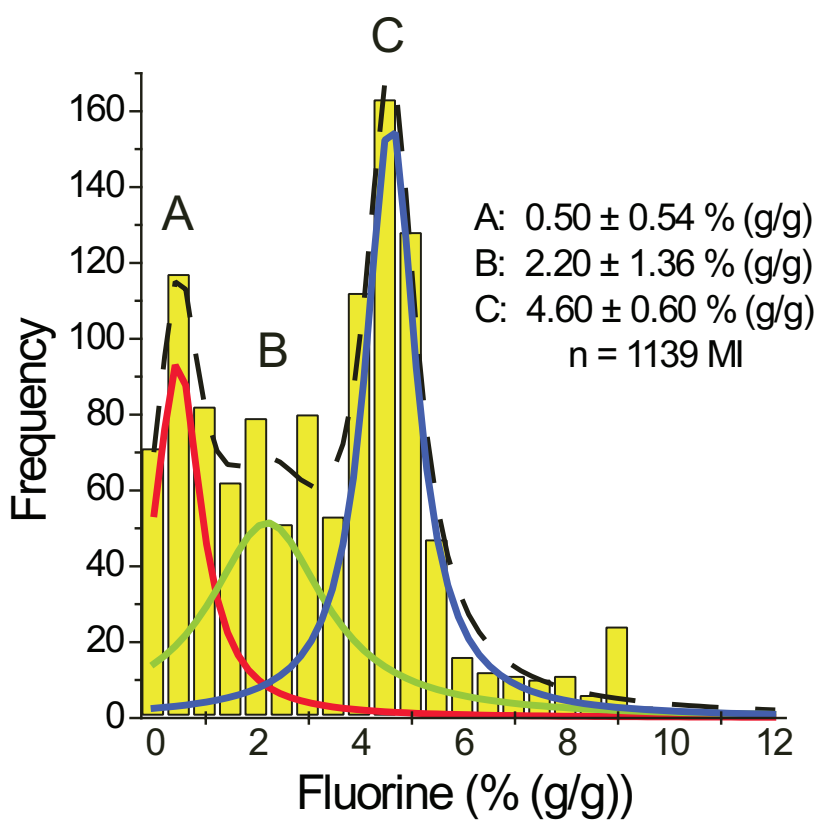

\section{(b) Melt inclusions in pegmatites}

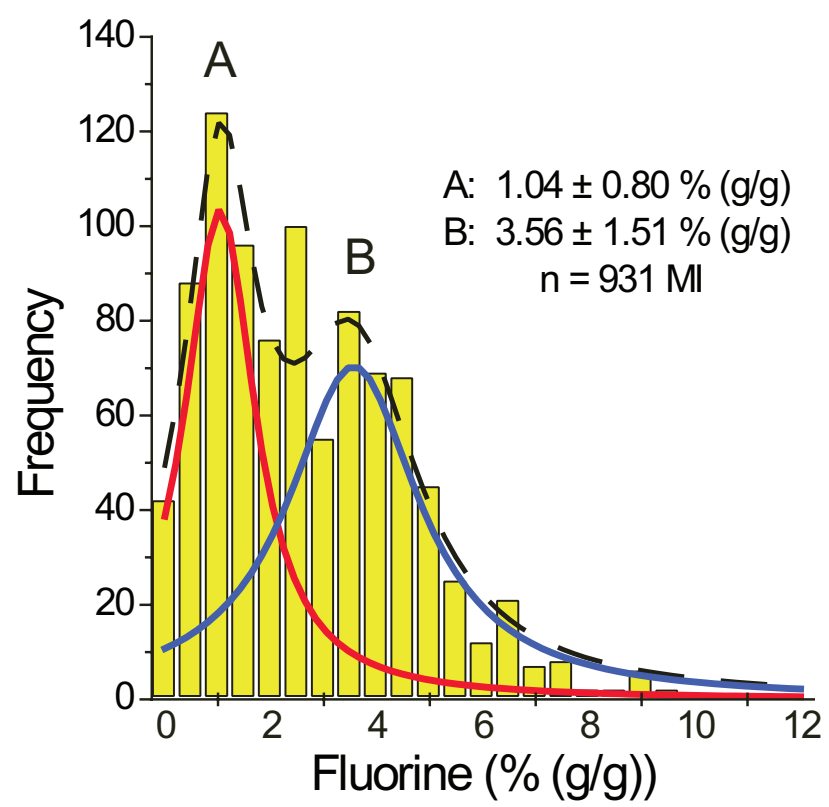

Fig. 7a - Frequency distribution of fluorine in melt inclusions in quartz of granites from the Erzgebirge region, Germany. b - Frequency distribution of fluorine in melt inclusions in pegmatite quartz related to the granites in (a).

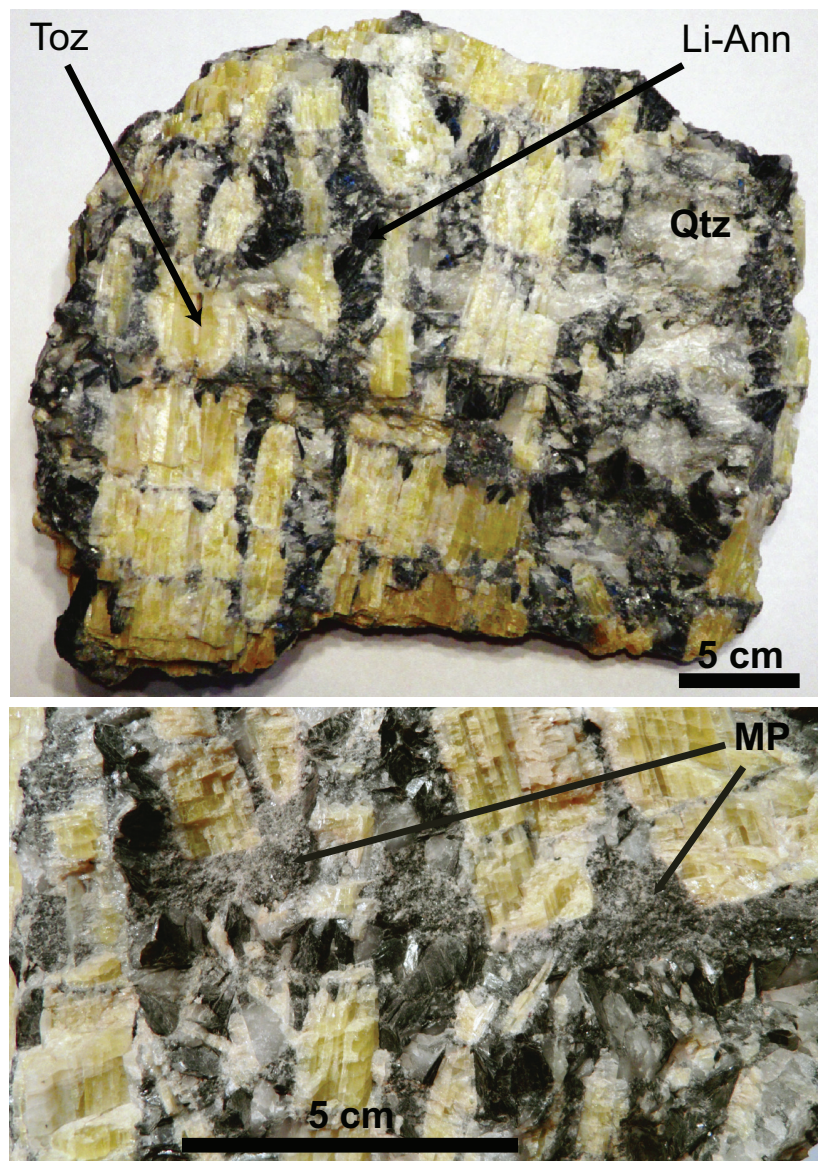

hold (2002) and our own estimates. Note that this is one of the most F-enriched magmatic rocks known, whose $\mathrm{F}$ contents exceed nearly six times those in the ongonite from Mongolia (Kovalenko and Kovalenko 1976; Christiansen et al. 1986). In the Altenberg granite the pycnite stockscheider, containing mainly topaz $(\sim 19.8 \%(\mathrm{~g} / \mathrm{g})$ F), quartz and lithian annite ("protolithionite"), is up to $15 \mathrm{~m}$ thick. Fluid inclusions in topaz are very salt-rich and contain halite as well as daughter crystals of villiaumite $[\mathrm{NaF}]$, cryolite $\left[\mathrm{Na}_{3} \mathrm{AlF}_{6}\right]$, chiolite $\left[\mathrm{Na}_{5} \mathrm{Al}_{3} \mathrm{~F}_{14}\right]$, cryolithionite $\left[\mathrm{Na}_{3} \mathrm{Li}_{3} \mathrm{Al}_{2} \mathrm{~F}_{12}\right]$, and REE-rich fluorite. Melt inclusions in topaz are very rare. In contrast, the quartz contains many melt inclusions (Tab. 2) and rarely the fluid inclusions typical of the topaz. Macroscopic remnants of K-feldspar in the pycnite zone as well as isolated $\mathrm{K}$-feldspar grains in the pycnite quartz suggest a two-step evolution: (i) primary formation of a feldsparquartz stockscheider pegmatite from a melt-dominated system, followed by (ii) an overprinting of strong F-rich supercritical solutions forming the palisade-like topaz (pycnite). Both processes were not separated by a large time hiatus and were related to the same intergranular system. The melt system changed over at the point of

Fig. 8 Photographs of the F-rich pycnite rock from the Sn-W deposit at Altenberg in the East Erzgebirge/Germany. Li-Ann - lithium annite, "protolithionite", Qtz - quartz, Toz - topaz. The lower photo shows former melt pockets (MP) with about the same composition as the bulk pycnite rock. 
Tab. 2 Modal comparison and calculated bulk compositions of the F-rich pycnite rock and the composition of large melt inclusions (MI) in pycnite quartz from Altenberg, eastern Erzgebirge, Germany

\begin{tabular}{lccc}
\hline & Pycnite-rock & Pycnite-rock & MI in pycnite $\left(\mathrm{Qtz}^{3}\right)$ \\
\hline $\mathrm{SiO}_{2}$ & $50.1 \pm 5.2$ & 64.8 & $72.17 \pm 2.39$ \\
$\mathrm{TiO}_{2}$ & $0.04 \pm 0.01$ & 0.20 & 0.02 \\
$\mathrm{Al}_{2} \mathrm{O}_{3}$ & $33.3 \pm 4.8$ & 21.0 & $11.65 \pm 0.42$ \\
$\mathrm{~B}_{2} \mathrm{O}_{3}$ & n.d. & 0.003 & $1.48 \pm 0.23$ \\
$\mathrm{FeO}$ & $4.7 \pm 1.3$ & 4.93 & $4.06 \pm 0.55$ \\
$\mathrm{MnO}$ & $0.21 \pm 0.06$ & 0.16 & $0.43 \pm 0.18$ \\
$\mathrm{MgO}$ & n.d. & 0.30 & $<0.02$ \\
$\mathrm{CaO}$ & n.d. & 0.80 & $<0.02$ \\
$\mathrm{Li} 2 \mathrm{O}$ & $0.61 \pm 0.19$ & 0.50 & $n . d$. \\
$\mathrm{Na}_{2} \mathrm{O}$ & $0.18 \pm 0.06$ & 0.20 & $1.33 \pm 0.27$ \\
$\mathrm{~K}_{2} \mathrm{O}$ & $2.49 \pm 0.76$ & 2.10 & $5.12 \pm 1.15$ \\
$\mathrm{Rb}_{2} \mathrm{O}$ & n.d. & 0.20 & $0.53 \pm 0.08$ \\
$\mathrm{Cs}_{2} \mathrm{O}$ & n.d. & 0.004 & $0.02 \pm 0.01$ \\
$\mathrm{~F}$ & $11.6 \pm 1.7$ & 5.60 & $3.01 \pm 0.82$ \\
$\mathrm{Cl}$ & n.d. & 0.10 & $0.34 \pm 0.08$ \\
$\mathrm{P}_{2} \mathrm{O}_{5}$ & n.d. & 0.09 & $\leq 0.04$ \\
\hline $\mathrm{Sum}$ & 103.23 & 100.99 & 100.24 \\
$\mathrm{Sum}_{\text {-corr }}$ & 98.36 & 98.61 & 98.90 \\
\hline $\mathrm{n}$ & & & 14 \\
\hline $\mathrm{n}$ & & &
\end{tabular}

$\mathrm{n}-$ number of studied inclusions

n.d. - not determined

n.1. - detection limit

${ }^{1}$ Calculated from the modal composition of the pycnite rock, determined from 24 different pycnite photos using the GeoPixelCounter program v. 1 (Mock et al. 2012); values in \% (vol/vol):

Quartz $28.7 \pm 8.8$

Topaz $\quad 44.2 \pm 9.7(\mathrm{~F}=19.8 \%(\mathrm{~g} / \mathrm{g})-$ Thomas 1982$)$

Li-annite $27.1 \pm 8.0(\mathrm{~F}=6.45 \%(\mathrm{~g} / \mathrm{g})-$ Rieder et al. 1970$)$

${ }^{2}$ According to Recknagel (1969), Weinhold (2002); however, these data are based on the wrong topaz reference (see Ossenkopf and Helbig 1975 ) and have been used in all papers since 1940.

${ }^{3}$ Water concentration is according to Raman spectroscopy $8.1 \pm 0.9 \%(\mathrm{~g} / \mathrm{g})$

pycnite crystallization into the fluid-dominated one due to the change in speciation of the $\mathrm{OH}^{-}$in the melt to molecular water. Owing to this change, $\mathrm{Na}$ and $\mathrm{F}$ formed stable compounds and partly migrated out of the meltfluid system and produced the observed sodium depletion in the melt inclusions and the pycnite rock (Tab. 2). Such high-temperature $\left(\sim 600^{\circ} \mathrm{C}\right)$ fluid systems are typical of the whole Variscan Erzgebirge.

As a further example the primary structure of large pegmatite quartz crystals from the Zinnwald deposit has been completely re-worked by highly corrosive and reactive fluids, conserved as fluid inclusions containing large daughter crystals of cryolite, chiolite and cryolithionite. The coexisting vapor-rich inclusions contain chiolite in the fluid phase, as well as often spherical crystals of native sulfur (Fig. 9). At high temperatures such fluids are extremely corrosive and reactive (Gorbaty and Bondarenko 1998), being probably responsible for the destruction of primary structure in the pegmatitic quartz crystals. After cooling to sub-critical temperatures $\left(\sim 400^{\circ} \mathrm{C}\right)$ the reactivity of the fluids decreases dramati- cally. The existence of F-rich melt and fluid inclusions in the Variscan granites of the Erzgebirge connected to the $\mathrm{Sn}-\mathrm{W}$ mineralization underscore the significance of fluorine in the region in the form of F-rich melt fractions and/ or extremely F-rich fluids (see also Johan et al. 2012). The similarity in the bulk composition, and especially the existence of occasional $\mathrm{F}$ enrichment in these inclusions, is a strong evidence that this pegmatite type could have been directly related to granites, and was formed at a late stage of the granite intrusion into the upper crust (Oelsner 1952).

Although extreme in pycnite rocks, $\mathrm{F}$ concentrations can be high in some MI in normal granites; Fig. 7a plots the frequency of fluorine concentrations of 1139 melt inclusions, mostly in quartz, from Variscan Erzgebirge granites. For comparison Fig. $7 \mathrm{~b}$ shows $\mathrm{F}$ concentrations in melt inclusions in pegmatite quartz related to the same granites. Compared to the bulk composition of granitic rocks (Förster and Romer 2010) examination of these histograms leads to the following conclusions.

(i) Peak A in Fig. 7a is the F concentration in the melt inclusions related to the primary crystallization of the granites, and as a rule is less than $2 \%(\mathrm{~g} / \mathrm{g})$, the mean is $0.50 \%(\mathrm{~g} / \mathrm{g})$ and corresponds to the bulk F concentration of the granite rocks (Hösel 1994; Förster and Romer 2010). (ii) All granites related to the $\mathrm{Sn}-\mathrm{W}$ mineralization contain some fluorine-rich melt inclusions, representing the intergranular filling (peak $\mathrm{C}$ in Fig. 7a). The F content (mean $\pm 1 \sigma$ ) of these inclusions is $4.6 \pm 0.6 \%(\mathrm{~g} / \mathrm{g})$, far higher than the highest whole-rock concentration $(0.93 \%$ $(\mathrm{g} / \mathrm{g})$ in the porphyritic albite-zinnwaldite microgranite dikes at Zinnwald and some F-rich fractions (peak B). (iii) The melt inclusions $(\mathrm{n}=931)$ in quartz of the pegmatites related to the Variscan granites of the Erzgebirge are

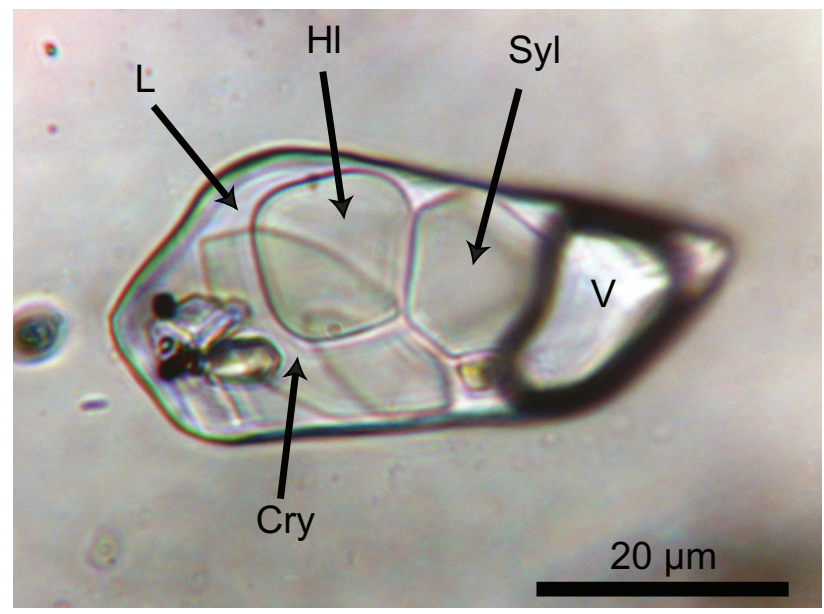

Fig. 9 Typical multi-phase fluid inclusion in topaz of the pycnite rock with cryolite, halite, sylvite and some un-identified daughter minerals. Cry - cryolite, Hl - halite, Syl - sylvite, L - salt-rich solution, V vapor. 
characterized by two maxima (Fig. 7b) at $1.04 \pm 0.80 \%$ $(\mathrm{g} / \mathrm{g})$ and $3.56 \pm 1.51 \%(\mathrm{~g} / \mathrm{g})$, representing two different pegmatite groups - one poor, and the other rich, in boron.

The results show clearly that the granite-forming magma was relatively F-poor and during fractional crystallization this element passed into the mobile residual melt in the intergranular space. Together with $\mathrm{H}_{2} \mathrm{O}, \mathrm{B}$, $\mathrm{P}$ and higher alkali concentrations this melt can form a highly mobile low viscosity intergranular melt (Fig. 10) which is often also enriched in rare elements such as $\mathrm{Li}$, $\mathrm{Rb}, \mathrm{Cs}, \mathrm{Nb}$ and $\mathrm{Sn}$ (Borisova et al. 2012). The viscosity of this melt would be further reduced by the partial crystallization of topaz, often observed in the Variscan granites related to $\mathrm{Sn}-\mathrm{W}$ mineralization and pegmatites, and reducing the aluminosilicate component of the melt. In large intergranular melt inclusions we often observed small topaz crystals. Due to the consumption of $\mathrm{Al}$ and $\mathrm{F}$ the melt acquired peralkaline characteristics. The coexis-
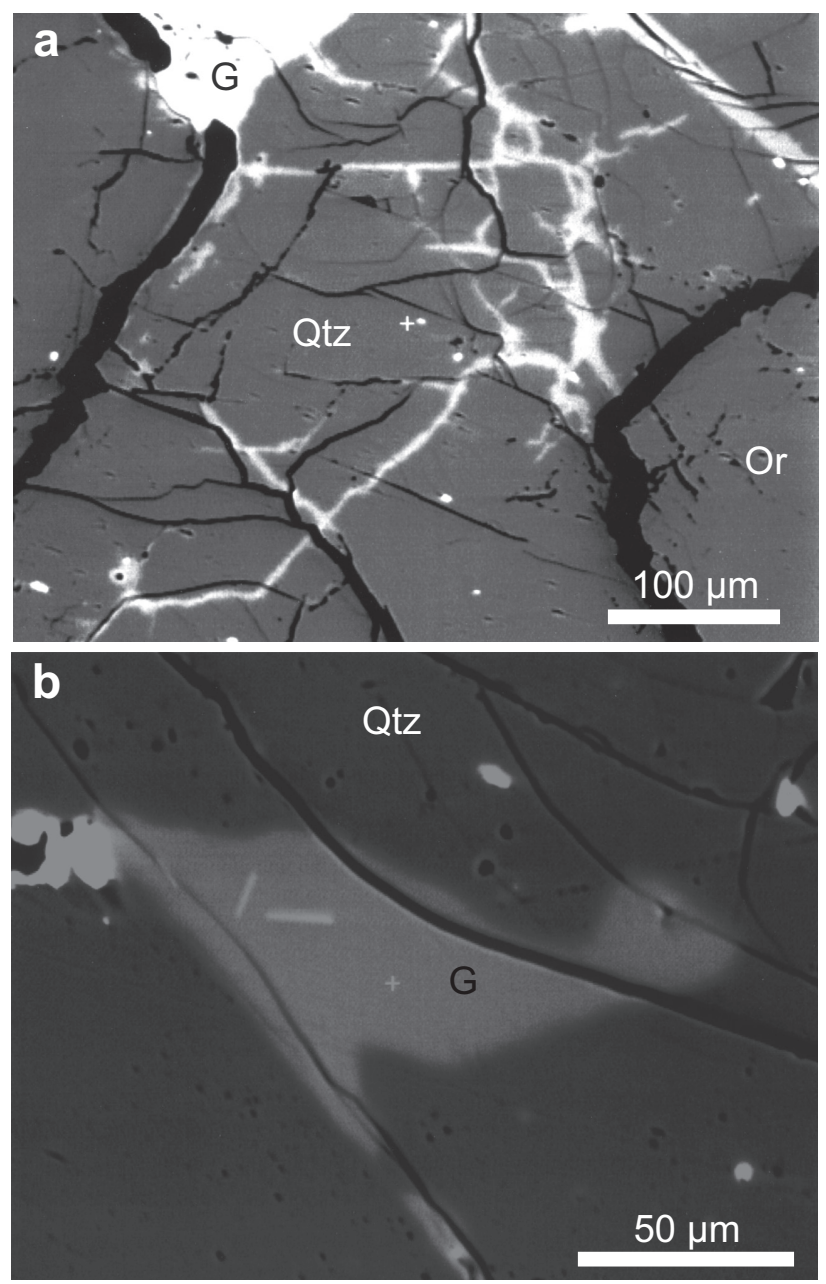

Fig. 10a - Back-scattered electron (BSE) image of intergranular melts (white) in quartz of the Greifenstein granite, Central Erzgebirge after re-homogenization at $800^{\circ} \mathrm{C} . \mathbf{b}-\mathrm{A}$ single intergranular melt inclusion in quartz of the same rock, G - glass, Qtz - quartz, Or - orthoclase. tence of fluid and melt inclusions in this topaz generation reflects the water-rich partial melt. Moreover, the F-rich melt and fluid inclusions demonstrate the juxtaposition of F-rich melt and F-rich fluids moving through the rock volume during the evolution of the granites. These hydrous partial melts and fluids can merge together and then form pegmatite schlieren, miaroles or stockscheiders inside the granite, or can leave the granite due to its high temperature and low viscosity and form pegmatite veins or bodies.

Given the dominance of $\mathrm{F}$ in the systems described, one point is commonly overlooked: F-rich systems often contain significant amounts of carbonates, indicated by the occurrence of accessory mineral phases such as REE fluorocarbonates (Johan et al. 2012) or carbonates (calcite, nahcolite) in high-temperature fluid inclusions (Zinnwald, Ehrenfriedersdorf, Pechtelsgrün and Orlovka). In Thomas et al. (2012b) we have shown that a large number of pegmatites, with or without high $\mathrm{F}$ concentrations, contain primary high concentrations of alkali carbonates. Furthermore, inclusions in minerals (quartz, topaz, cassiterite or wolframite) of the $\mathrm{Sn}-\mathrm{W}$ deposits related to the F-rich Variscan granites mentioned above, often contain alkali carbonate-rich solutions (sometimes up to $1.2 \%(\mathrm{~mol} / \mathrm{mol}))$ often with $\mathrm{CO}_{2}$ and $\mathrm{CH}_{4}$ in the vapor phase.

\subsection{Phosphorus content of melt inclusions}

Because of the smaller number of samples analyzed for $\mathrm{P}$, the following comments on the significance of this element for the separation and formation of graniterelated pegmatites are restricted to some granites from the Variscan Erzgebirge. Most MI in granites of this region have $\mathrm{P}_{2} \mathrm{O}_{5}$ concentrations $\leq 0.18 \%(\mathrm{~g} / \mathrm{g})(\mathrm{n}=604)$, especially the granites with A-type characteristics of the Altenberg-Teplice Caldera (Breiter 2012 and references therein). However MI of some S-type granites, especially the granites around Ehrenfriedersdorf, Podlesí, and some of the Eibenstock Massif are characterized by higher $\mathrm{P}$ concentrations (Fig. 11a). Melt inclusions in these granites contain $0.58 \pm 0.09 \%(\mathrm{~g} / \mathrm{g}) \mathrm{P}_{2} \mathrm{O}_{5}(\mathrm{n}=225)$. Some inclusions contain higher concentrations, from $1.0 \%$ up to $10 \%(\mathrm{~g} / \mathrm{g}) \mathrm{P}_{2} \mathrm{O}_{5}(\mathrm{n}=67)$, and we interpret these to represent former intergranular melts. Melt inclusions of the un-specialized Erzgebirge granites contain only 0.06 $\pm 0.02 \% \mathrm{P}_{2} \mathrm{O}_{5}(\mathrm{n}=584)$ in comparison.

From the frequency distribution of $\mathrm{P}$ for melt inclusions in pegmatites related to the P-rich granites four maxima can be obtained (Fig. 11b): $<0.9(\mathrm{n}=405), 2.7$ $\pm 0.8(\mathrm{n}=510), 4.2 \pm 0.4(\mathrm{n}=448), 6.6 \pm 0.8(\mathrm{n}=131)$. In contrast to $\mathrm{F}, \mathrm{P}$ is much more strongly enriched during the pegmatite-forming processes. Depending on the melt inclusion type, $\mathrm{P}$ is generally associated with $\mathrm{Al}$ in berlin- 
ite $\left[\mathrm{AlPO}_{4}\right]$ in the water-poor inclusions, and with alkali phosphates, such as amblygonite $\left[\mathrm{LiAl}\left(\mathrm{PO}_{4}\right)(\mathrm{F}, \mathrm{OH})\right]$ or lacroixite $\left[\mathrm{NaAl}\left(\mathrm{PO}_{4}\right) \mathrm{F}\right]$ in the most water-rich melt inclusions (Rickers et al. 2006). Another P-bearing daughter mineral in the water-rich melt inclusions in quartz of the Ehrenfriedersdorf pegmatite is beryllonite $\left[\mathrm{NaBePO}_{4}\right]$ (Thomas et al. 2011a). Furthermore, during the crystallization of P-rich pegmatite, extremely P-rich melt patches occur as individual MI in the range of 10-100
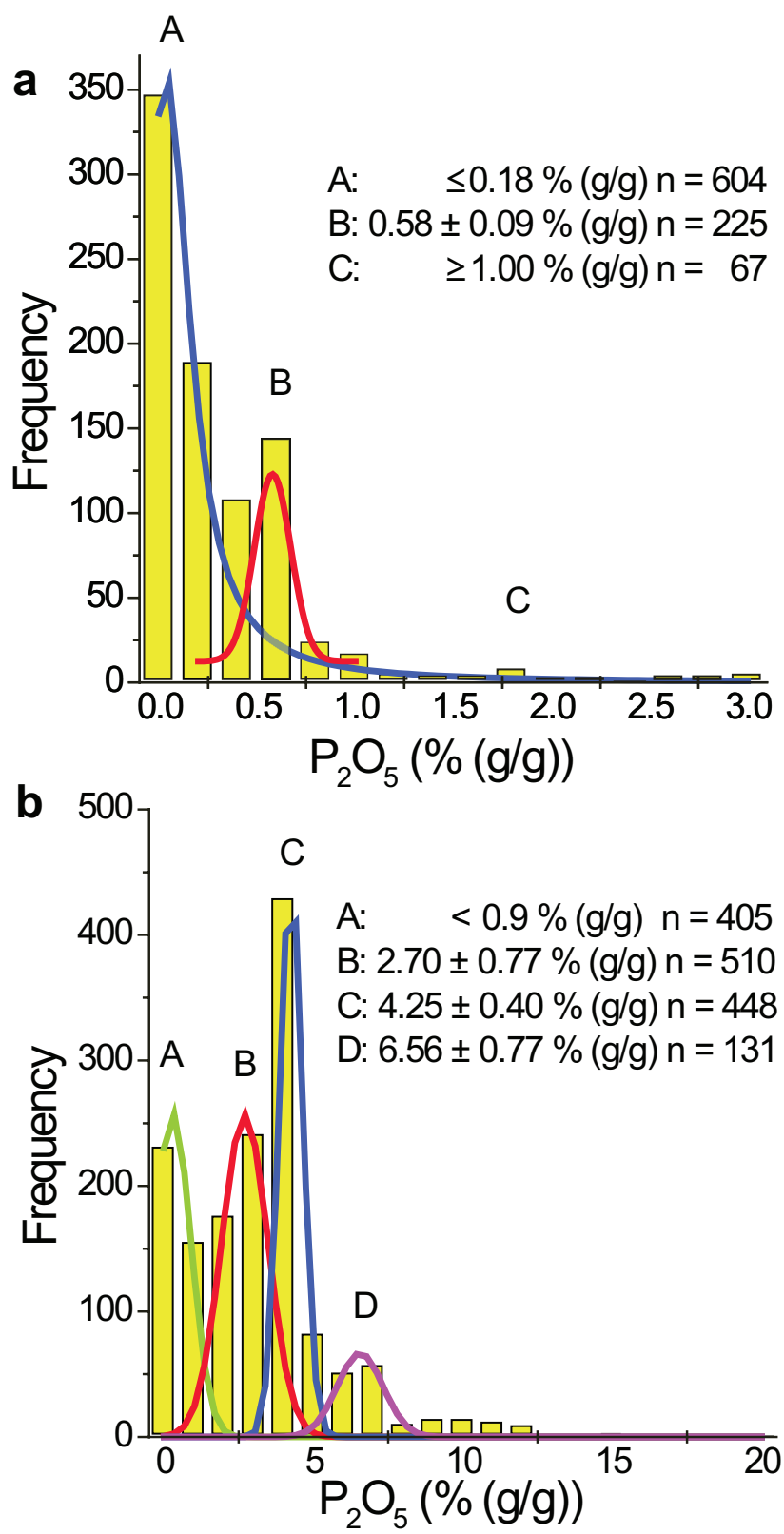

Fig. 11a - Frequency distribution of $\mathrm{P}_{2} \mathrm{O}_{5}$ in melt inclusions (MI) of quartz from the Central Erzgebirge region, Germany (Ehrenfriedersdorf, Greifenstein granite, Podlesí, Eibenstock Massif). b - Frequency distribution of phosphorus in melt inclusions of pegmatite quartz related to the granites in a). $\mu \mathrm{m}$, or macroscopically as centimeter-sized globules or deformed intercrystal fillings between orthoclase crystals. Composition varies from patch to patch - amblygonite $\left[\mathrm{LiAl}\left(\mathrm{PO}_{4}\right)(\mathrm{F}, \mathrm{OH})\right]$, berlinite, isokite $\left[\mathrm{CaMg}\left(\mathrm{PO}_{4}\right) \mathrm{F}\right]$ or zwieselite $\left[\left(\mathrm{Fe}^{2+}, \mathrm{Mn}^{2+}\right)_{2}\left(\mathrm{PO}_{4}\right) \mathrm{F}\right]$ can occur with $\mathrm{P}_{2} \mathrm{O}_{5}$ up to $51 \%(\mathrm{~g} / \mathrm{g})($ Fig. 12 and Tab. 3) - see also Thomas et al (1998). Note that $\mathrm{P}_{2} \mathrm{O}_{5}$-rich glass is water soluble, so in normal thin-section preparation the P-rich portions may be depleted.

Tab. 3 Composition of typical P-rich melt inclusions (MI) in quartz of the Ehrenfriedersdorf granite, central Erzgebirge, Germany (re-calculated to water-free basis) and some P-rich MI in the pegmatite related to this granite

\begin{tabular}{lccc}
\hline & $\begin{array}{c}\text { MI in granite } \\
\text { Quartz }\end{array}$ & $\begin{array}{c}\text { MI in P-rich pegmatite } \\
\text { Quartz }\end{array}$ & $\begin{array}{c}\text { P-rich } \\
\text { MI in Pegmatite } \\
\text { Quartz }^{1}\end{array}$ \\
\hline $\mathrm{SiO}_{2}$ & $66.25 \pm 1.40$ & $59.8 \pm 1.6$ & $10.6 \pm 2.2$ \\
$\mathrm{TiO}_{2}$ & $0.10 \pm 0.01$ & 0.1 & 0.01 \\
$\mathrm{Al}_{2} \mathrm{O}_{3}$ & $17.18 \pm 1.30$ & $19.7 \pm 0.3$ & $36.6 \pm 1.6$ \\
$\mathrm{~B}_{2} \mathrm{O}_{3}{ }^{2}$ & $0.25 \pm 0.16$ & n.d. & n.d. \\
$\mathrm{FeO}$ & $0.47 \pm 0.06$ & $0.5 \pm 0.1$ & $0.24 \pm 0.06$ \\
$\mathrm{MnO}$ & $0.11 \pm 0.06$ & 0.03 & 0.03 \\
$\mathrm{MgO}$ & 0.04 & d.1. & 0.02 \\
$\mathrm{CaO}$ & $0.14 \pm 0.03$ & $0.06 \pm 0.01$ & 0.02 \\
$\mathrm{Li}_{2} \mathrm{O}^{2}$ & $0.53 \pm 0.24$ & n.d. & n.d. \\
$\mathrm{Na}_{2} \mathrm{O}$ & $3.85 \pm 0.70$ & $5.2 \pm 0.2$ & $0.52 \pm 0.2$ \\
$\mathrm{~K}_{2} \mathrm{O}$ & $3.55 \pm 0.90$ & $2.6 \pm 0.1$ & $0.64 \pm 0.4$ \\
$\mathrm{Rb}_{2} \mathrm{O}^{2}$ & $0.26 \pm 0.07$ & $0.6 \pm 0.1$ & n.d. \\
$\mathrm{Cs}_{2} \mathrm{O}^{2}$ & $0.03 \pm 0.02$ & n.d. & n.d. \\
$\mathrm{F}$ & $3.95 \pm 0.04$ & $4.2 \pm 0.1$ & d.l. \\
$\mathrm{Cl}$ & 0.03 & 0.21 & 0.03 \\
$\mathrm{P}_{2} \mathrm{O}_{5}$ & $3.26 \pm 0.10$ & $6.9 \pm 0.4$ & $51.3 \pm 3.5$ \\
\hline $\mathrm{Sum}$ & 100.00 & 99.9 & 100.01 \\
\hline $\mathrm{n}$ & 14 & 23 & 16 \\
\hline
\end{tabular}

${ }^{1}$ according to Thomas and Webster (1999)

2 determined by NIR femtosecond LA-ICP-MS (Borisova et al. 2012), mean of $10 \mathrm{MI}$

d.1. - detection limit, n.d. - not determined, $\mathrm{n}$ - number of studied MI

Generally, the influence of $\mathrm{P}$ on the viscosity and water solubility is significantly lower than that of $\mathrm{H}_{2} \mathrm{O}, \mathrm{F}$, B, and alkalis (Johannes and Holtz 1996; Sowerby and Keppler 2002; Bartels et al. 2011, 2013) and by itself cannot reduce the viscosity down to values of $c .10^{2} \mathrm{~Pa} . \mathrm{s}$ at $700{ }^{\circ} \mathrm{C}$ which are considered to be the threshold values for the separation of residual melt (McKenzie 1985) except at very high concentrations. Although $\mathrm{P}$ is often significantly enriched in intergranular melts, and has been considered a possible fluxing element, it appears to be of less importance than $\mathrm{F}$ or $\mathrm{B}$.

\subsection{Boron content of melt inclusions}

The Malkhan pegmatites in Transbaikalia, Russia give a further example of the pegmatite formation via a 
water- and boron-rich melt systems moving in part as supercritical fluid through the parental granite (Thomas et al. 2012a). This system is partly also rich in carbonates as new studies have shown. Some early water-rich melt inclusions contain about $1.1 \%(\mathrm{~mol} / \mathrm{mol})$ alkali carbonates as well as boric acid and liquid $\mathrm{CO}_{2}$ at room temperature. The homogenization behavior implies the following reaction:

$$
2 \mathrm{H}_{3} \mathrm{BO}_{3}+3 \mathrm{Na}_{2} \mathrm{CO}_{3} \rightarrow 2 \mathrm{Na}_{3} \mathrm{BO}_{3}+3 \mathrm{CO}_{2}+3 \mathrm{H}_{2} \mathrm{O} \text {. }
$$

At ambient pressure and under boiling conditions it proceeds to completion to the right and is a first order

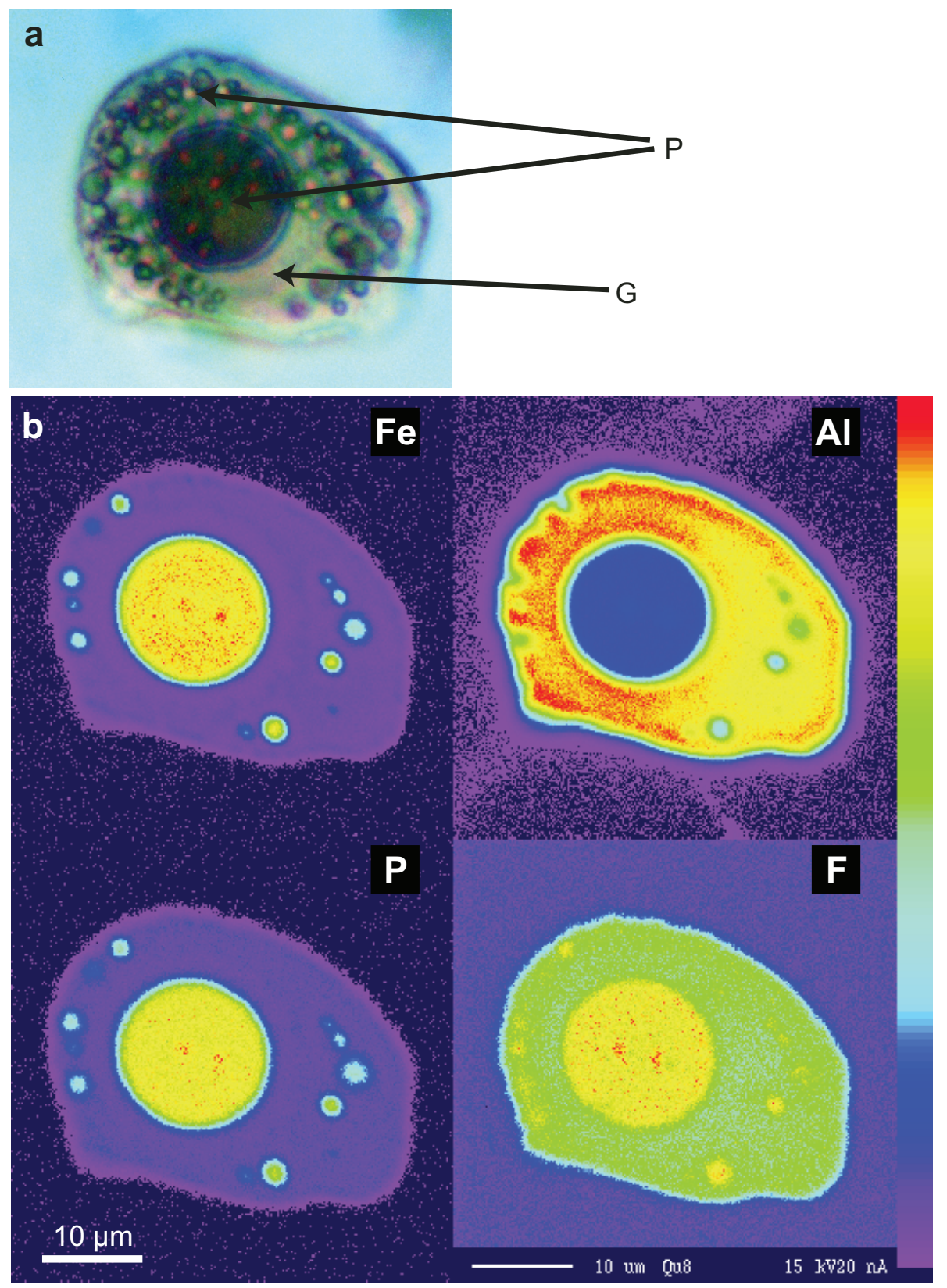

reaction (Gmelin 1954). At higher pressure the reaction obeys the law of mass action reverse and provides a separation mechanism for boric acid and alkali carbonates, often observed in different deposits (Zinnwald, Ehrenfriedersdorf, Pechtelsgrün, Orlova, Malkhan and many others) by the process of liquid-liquid-fluid immiscibility and pressure fluctuations (Thomas et al. 2012a). In connection with the evolution of the gel state in the direction of the quartz core (Thomas and Davidson 2012b) such reaction types can be very effective on the micro- and macro scale for the nearly perfect separation and enrichment of elements such as Cs (Thomas and Davidson 2012a) or the separation of Hf and Zr, forming hafnon $\left[\mathrm{HfSiO}_{4}\right]$ near the quartz core of some pegmatites.

That melt inclusions in the F-dominated granite-pegmatite systems of the Variscan Erzgebirge can also contain significant amounts of boron can be seen from Fig. 13. Peak A represents the boron concentration in melt inclusions in quartz from granites and peaks B and $\mathrm{C}$ for the related pegmatites. Boron is not only connected to typical B-bearing minerals (e.g. tourmaline). Mica and feldspars from the Ehrenfriedersdorf pegmatites contain relatively high $\mathrm{B}$ (as $\mathrm{B}_{2} \mathrm{O}_{3}$ ) concentrations: up to $8.5 \%$ in B-muscovite, $4.6 \%$ in B-rich mica, $0.75 \%$ in B-poor mica, and up to $2.3 \%$ in $\mathrm{K}$ - and $\mathrm{Na}-$ feldspars (Thomas et al. 2003). Furthermore, secondary fluid inclusions in quartz of many Variscan granites from Erzgebirge contain higher boric acid concentrations (recalculated to $\mathrm{B}_{2} \mathrm{O}_{3}$ ). Two groups were ob-

Fig. 12 An extremely P-rich melt inclusion in pegmatite quartz from Ehrenfriedersdorf after re-homogenization. a - Photograph of a melt inclusion with an extremely P-rich globule in quartz. $\mathrm{G}$ - silicate glass, $\mathrm{P}-\mathrm{P}_{2} \mathrm{O}_{5}$-rich glass. $\mathbf{b}$ - Microprobe images of the $\mathrm{Fe}$, $\mathrm{Al}, \mathrm{P}$, and $\mathrm{F}$ distribution of the same inclusion. The intensity scale on the right side shows the relative concentration of the elements. 


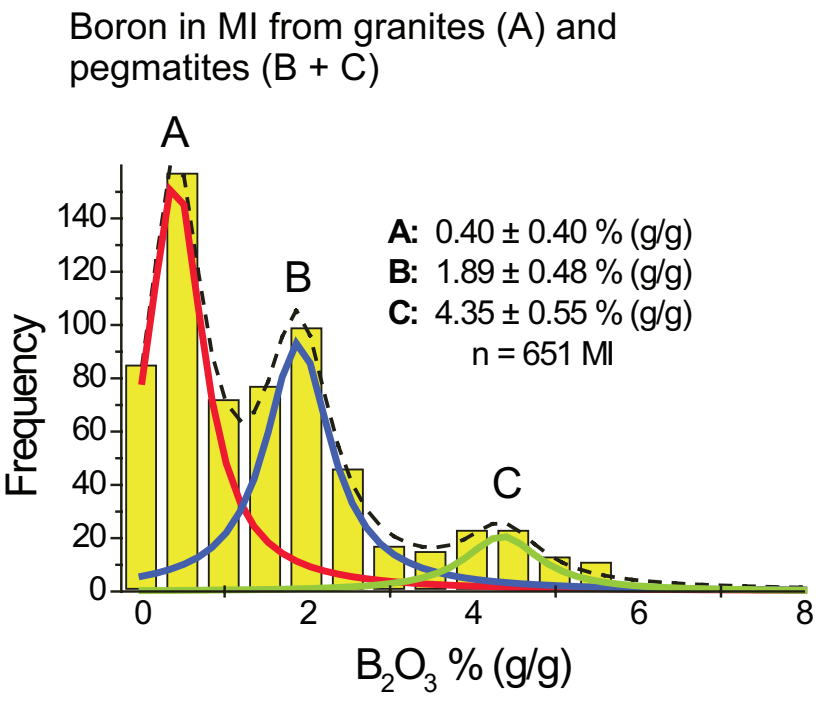

Fig. 13 Frequency distribution of $\mathrm{B}_{2} \mathrm{O}_{3}$ in melt inclusions in quartz of granites and pegmatites from the Erzgebirge region, Germany.

tained from Raman spectroscopic measurements on 80 different samples:

$$
\begin{aligned}
& 0.50 \pm 0.56 \%(\mathrm{~g} / \mathrm{g}) \mathrm{B}_{2} \mathrm{O}_{3}(\mathrm{n}=52) \\
& 2.08 \pm 0.31 \%(\mathrm{~g} / \mathrm{g}) \mathrm{B}_{2} \mathrm{O}_{3}(\mathrm{n}=28) .
\end{aligned}
$$

The first group represents fluid inclusions with homogenization temperatures lower than $300^{\circ} \mathrm{C}$ and the second between 600 and $300{ }^{\circ} \mathrm{C}$.

The granites in the Variscan Erzgebirge region are characterized by the moderate and/or very high degree of separation and enrichment of $\mathrm{H}_{2} \mathrm{O}, \mathrm{F}, \mathrm{B}, \mathrm{P}$, and alkalis in the intergranular melts, reducing their viscosity and increasing the mobility and tendency for separation from the granite allowing an independent evolution. In other granite bodies the order and concentration of the above-mentioned volatiles and elements can be different. In some regions B is the dominant species (Malkhan and Rangkul), in others prevail alkali carbonates (Rønne, Froland and Borborema), or different combinations thereof (Thomas et al. 2009a). By variation in the $\mathrm{P}-\mathrm{T}$ regime the timing of speciation changes in the mobile phases can vary within wide limits and can be responsible for the differential mobility of different components (Korzhinskii 1970). The change over from the melt-dominated into the supercritical or fluid state at near magmatic conditions determines the chemical character of the mobile pegmatite-forming phases. If the regime changes over into the postmagmatic state, only pneumatolytic and/or hydrothermal formations are possible. In this case true pegmatites can only be formed if large amounts of boron or alkalis are present in the melt (Mustart 1972).

\subsection{Other viscosity-reducing elements in pegmatite-forming melts}

Within the scope of this contribution we will briefly show other possible scenarios, not including F, P, or B as the "critical" elements. The study of the pegmatites connected to the Rønne granite on the Bornholm Island, Denmark showed that higher concentrations of alkali carbonates together with water can serve as viscosity-reducing agents for pegmatite formation (Thomas et al. 2011b; Thomas and Davidson 2012a), especially for the separation of the mobile volatile-rich melt from the matrix.

This is also true for the pegmatitic granites of the Borborema Pegmatite Field, Brazil. This rock is poor in fluorine and boron, but contains many very nahcolite-rich inclusions in quartz and feldspars, mostly near the grain boundaries, indicating an alkali carbonate- and water-rich melt moving at a late stage through the grain boundary spaces. Due to this low viscosity of the intergranular melt, the diffusion coefficients of most elements increased by several orders of magnitude and allowed the crystallization of larger quartz and feldspars crystals. Furthermore we infer that the water- and alkali-rich intergranular melt was responsible for the strong metasomatic albitization of feldspars near grain boundaries. We would suggest that similar situations may be common, as Thomas et al. (2012b) have shown that carbonate-rich MI in pegmatite systems are not rare. In addition, high concentrations of alkali carbonates are an important connecting link to the gel-sol state during the pegmatite evolution (Thomas and Davidson 2012b).

We have shown (Thomas et al. 2012b) that the experimental results of Mustart (1972) are very important for the crystallization of pegmatite melts without significant amounts of the typical elements B, F, and P. Here excess alkalis can increase the water solubility with decreasing temperature to very high values. According to Mustart (1972) the addition of any amount of sodium disilicate to an albite- $\mathrm{H}_{2} \mathrm{O}$ melt will increase the water-solubility of a feldspar-saturated liquid in water from $15 \%(\mathrm{~g} / \mathrm{g}) \mathrm{H}_{2} \mathrm{O}$ at $700{ }^{\circ} \mathrm{C}, 21 \%$ at $600{ }^{\circ} \mathrm{C}$, and up to $43 \%(\mathrm{~g} / \mathrm{g})$ at $530^{\circ} \mathrm{C}$ depending on the amount of excess alkali silicate added.

\section{Melt-melt immiscibility and the granite-pegmatite transition}

The composition of the "anomalous" melt inclusions in granite shows strong enrichment in volatiles, leaving little doubt that they represent highly evolved volatile-enriched residual melts. As shown previously, these volatiles can have very strong effects on melt viscosity even in relatively small concentrations, but they are fugitive, being readily lost by degassing, and analysis of the crystallized 
rocks gives little if any guide to their original concentrations in the melt.

In natural magmas surprisingly large concentrations of volatiles are completely miscible with granitic melts at their normal temperatures and pressures. However, many experiments have shown that the presence of elevated concentrations of these volatiles expands the miscibility gap over a wide TPX range (e.g. Fig. 5), resulting in the separation of two or more conjugate melts, each with distinctively different compositions (see also figure 4 in Thomas et al. 2012a and the experimental work of Mustart (1972), Bureau and Keppler (1999), Thomas et al. (2000), Sowerby and Keppler (2002), Veksler et al. (2002) and Audétat and Keppler (2004)). Of particular interest in pegmatites are type-A and B melts (using the nomenclature of Thomas et al. (2000) and Thomas and Davidson (2012a)) interpreted to represent two conjugate melt fractions, one evolving to more peraluminous and less water-rich compositions (type-A melts) and the second to more peralkaline and very water-rich compositions (type-B melts) relative to their parental melt, whatever its composition was prior to melt-melt immiscibility. In a database of several thousand analyses from dozens of different pegmatites worldwide type-A melt inclusions average $10.5 \pm 8.1 \%(\mathrm{~g} / \mathrm{g}) \mathrm{H}_{2} \mathrm{O}$, and type-B MI average

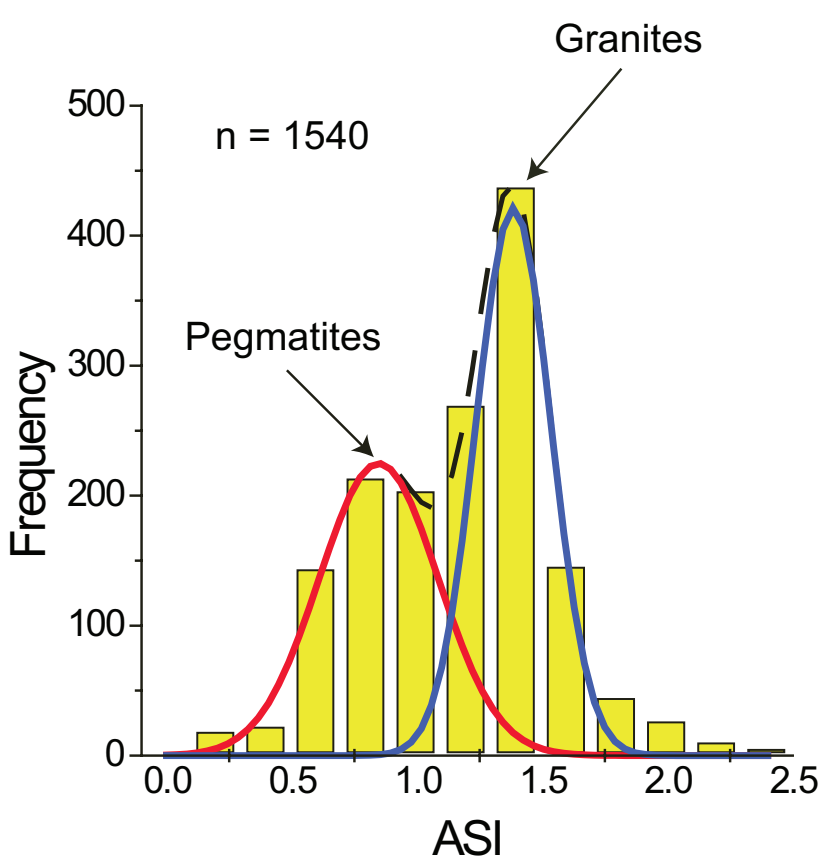

Granites: $\quad A S I=1.385 \pm 0.150$

Pegmatites: $\mathrm{ASI}=0.847 \pm 0.238$

Fig. 14 Frequency distribution of ASI (alumina saturation index) obtained from 1540 microprobe analyses of melt inclusions in quartz of granites $(n=832)$ and pegmatites $(n=708$, mostly from the Erzgebirge region). The average of all data (ASI $=1.094 \pm 0.268$ ) corresponds to the mean of peraluminous granites (Clarke 1992).
$26.2 \pm 14.3 \%$ (g/g) $\mathrm{H}_{2} \mathrm{O}$ (Thomas and Davidson, 2012a). These melt compositions are found preserved as melt inclusions in minerals in pegmatites, and less commonly in granites.

Inherently the timing of melt-melt immiscibility can only be constrained to being after the exsolution of a volatile-rich residual melts and prior to the trapping of type-A and B MI. Residual melts in granites should come from greater depths and thus be hotter than melts at pegmatite levels, and above the crest of the miscibility curve. Thus the residual melt would be most likely (at least initially) extracted as a single phase. With extraction from the granite, and consequent cooling, melt-melt immiscibility would most likely occur either during transport to the site of pegmatite formation, or immediately upon injection into it, whenever the temperature of the residual melt intersects the two-melt stability field for the given composition (Fig. 5). Thus MI trapped in granites most probably represents volatile-rich singlephase residual melt, possibly with some overlay of type-A and B melts. From a frequency plot of ASI (alumina saturation index; uncorrected for apatite): moles of $\left.\mathrm{Al}_{2} \mathrm{O}_{3} /\left[\mathrm{CaO}+\mathrm{Na}_{2} \mathrm{O}+\mathrm{K}_{2} \mathrm{O}+\mathrm{Rb}_{2} \mathrm{O}+\mathrm{Cs}_{2} \mathrm{O}\right]\right)$ obtained from microprobe analyses of a large number of melt inclusions in granite and pegmatite quartz (Fig. 14) a significant change in chemistry can be seen: the average of ASI for the granitic residual and the pegmatite melts are $1.38 \pm$ 0.15 and $0.85 \pm 0.24$, respectively. This means that in the more mobile pegmatite-forming melts the alkalis are more enriched relative to aluminum, and in the granitic residual melts ASI show the reverse trend (Marakushev and Gramenitskiy 1983). The larger standard deviation for the pegmatite-related data probably results from the separation into the two conjugate melt fractions.

In pegmatites type-A and B MI are commonly found randomly mixed together in the same trapping planes suggesting an original emulsion of the two melts. Note, however, that due to the different wetting behaviors of the two partial melts, the observed ratio probably does not correspond to their primary proportions. After emplacement of such an emulsion into cooler wall-rocks each phase would evolve independently, with back-reaction between the phases, assimilation of wall-rocks and previously crystallized minerals, and degassing providing an extremely dynamic, corrosive, high-energy, and probably non-equilibrium environment in which pegmatites would evolve. Moreover, due to density and viscosity contrast, gravity separation of these melts is possible. As an example, in the Ehrenfriedersdorf (Sauberg mine), steeply dipping, more than $10 \mathrm{~cm}$ thick, zircon-rich beryl-quartz veins in the country rock only contain type-B MI in quartz and beryl; however, the pegmatite veins from which they radiate host typical populations of mixed type-A and B inclusions. Gravity separation may also 
explain the vertical zoning found in some pegmatites in addition to the typical concentric zoning (Jahns 1982).

\section{Discussion}

The crystallization of nominally water-free rock-forming minerals (quartz, feldspars) from granite magmas drives an initially homogeneous system gradually into a heterogeneous one containing a more or less stationary solid phase and a mobile residual melt/fluid phase in some respects similar to a chromatographic column. Due to compaction, their density contrast and, in particular, lower viscosity, the separated mobile phase moves through the column and along the way sequesters all of the available granite-incompatible elements. By this "purification" process a more or less pure haplogranite rock remains. As a corollary however, there must be the production of a residual melt strongly enriched in water, F, B, alkali carbonates and bi-carbonates, and all of the other haplogranite-incompatible elements in different proportions, depending on the chemistry of the precursors.

In this study we have documented the existence of generally small but significant populations of melt inclusions in minerals from common granites which show "abnormal" compositions, relative to the bulk granite, but which are consistent with just such volatile-enriched residual melt. Moreover, given the available experimental evidence of the effects of these elements on the melting temperatures regarding felsic melts, we can be confident from the extreme composition of these residual melts that they must have had a very low viscosity and a strongly enhanced ability to separate from their host, which at this point was effectively solid due to its high crystal content. The conditions under which it is realistically possible to extract residual melt from a crystal mush, particularly at the last stages of crystallization, require a melt composition different from its parental melt.

McKenzie (1985) suggested that acidic melts will only be able to move with respect to their partly crystallized matrices if their viscosity is less than about $10^{2}$ Pa.s, which is several orders of magnitude lower than the viscosities of typical granite magmas at geologically reasonable temperatures. If we accept the current view that pegmatites form from residual melts extracted at the late-stage crystallization, and thus are enriched in rare elements that make some pegmatites important economic assets, then we cannot ignore also the enrichment in those economically insignificant elements which may have a profound effect on the physical properties of the residual melts. Since these elements are inherently fugitive, whole-rock compositions give only poor constraints on the compositions of feasible residual melts from which pegmatites could form, and currently only melt inclusions can provide a means of estimating pre-trapping, and therefore pre-degassing melt compositions.

The degree of incompatibility, the combination and concentration of these elements mirrors the source and type of the granite magmas and also the resulting pegmatite melts. There are however other possibilities for the introduction of the haplogranite extraneous elements, e.g., by the input of transmagmatic fluids or by the contamination during the ascent of the granite magma. Careful isotope studies can help here to decipher the origin of individual elements that take part in the formation of granitic pegmatites. Independent of the specific origin of the intergranular melts, they are the missing link which closes the gap in pegmatite evolution proposed at the beginning of this paper.

\section{Conclusions}

Careful study of the melt-inclusion inventory in minerals of granites has shown that as well as inclusions representing the equilibrium bulk-rock compositions there are some which bear little resemblance to the host granite. Moreover, the relative abundance of the latter inclusions is related to the presence or absence of pegmatites associated with the particular granite intrusion, being almost absent in granites that have no clearly related pegmatites but being abundant in those that do. Such "anomalous" inclusions are typically located towards the margins of crystals, and are enriched in all the elements which do not fit into the ideal granite system. These inclusions show strongly elevated concentrations of water, F, B, P, alkali carbonates and bicarbonates, and show similar compositional ranges within a given granite, but vary widely among different granite plutons. Examples of granite intrusions with populations of these inclusions dominated by F, B, or carbonates, and some with mixed populations have been described. The variation between their compositions is consistent with variations in the incompatible-element concentrations in their respective hosts. As melts these compositions would have the low viscosity and high mobility required to escape from the rheologically solid granites, and to preferentially sequester just those elements that can be so notably concentrated in pegmatites. For these reasons we interpret these inclusions to be trapped from intergranular residual melts, and as a result of their composition the mobile residual phase could form pegmatite-forming melts or metasomatic fluids depending on $\mathrm{P}-\mathrm{T}$ conditions. We have shown that such inclusions occur in a number of different granites, although given their rarity they are most easily found where there is a sufficiently large number of MI analyses for statistical analysis.

The critical feature of these "anomalous" melt inclusions in granite is their extremely low viscosity, as shown 
in homogenization experiments. It is noteworthy as it provides a mechanism by which very small proportions of highly fractionated melt can be extracted from almost solidified granites. Moreover, this low viscosity as well as several other important features of highly fractionated residual melts is a direct result of their compositions. Therefore, these inclusions provide some constraints on the actual compositions of mobile residual melt phases and they seem to be an important starting point in the evolution of pegmatites. Thus such compositions should represent a promising target of pegmatite experiments.

Acknowledgements. We thank Barrie Clarke (Halifax) for samples from the Lake Lewis leucogranite, Nova Scotia, Canada and the late Vyacheslav Ivanovich Kovalenko (1936-2010) who promoted our work on the apogranites and related pegmatites in eastern Transbaikalia together with Elena Badanina from St. Petersburg. Thanks go especially to Dieter Rhede and Oona Appelt from the GFZ Potsdam for the help with microprobe analyses over many years. For clarifying discussion about the Altenberg deposit the authors thank Günter Weinhold (Freiberg). Otto Leeder (Freiberg) is also thanked for his contributions to the significance of liquation for our "missing link" problem, which goes back to the mid-eighties. The studies of Anastassia Borisova have been very instructive in the origin of differences in the trace-element characteristics of the inclusion inventory of granites and their pegmatites.

Karel Breiter, and one anonymous referee are thanked for their constructive reviews and suggestions. The paper benefited from the careful handling by the Editor Pavel Uher and the Editor-in-Chief Vojtěch Janoušek.

\section{References}

Audétat A, Keppler H (2004) Viscosity of fluids in subduction zones. Science 303: 513-516

Bartels A, Behrens H., Holtz F, Schmidt BC, Fechtelkorn M, Knipping J, Crede L, Baasner A, Pukallus N (2013) The effect of fluorine, boron and phosphorus on the viscosity of pegmatite forming melts. Chem Geol 346: 184-198

Bartels A, Vetere F, Holtz F, Behrens H, Linnen RL (2011) Viscosity of flux-rich pegmatitic melts. Contrib Mineral Petrol 162: 51-60

Borisova AY, Thomas R, Salvi S, Candaudap F, Lanzanova A, Chmeleff J (2012) Tin and associated metal and metalloid geochemistry by femtosecond LA-ICP-QMS microanalysis of pegmatite-leucogranite melt and fluid inclusions: new evidence for melt-melt-fluid immiscibility. Mineral Mag 76: 91-113

BREITER K (2012) Nearly contemporaneous evolution of the A- and S-type fractionated granites in the Krušné hory/ Erzgebirge Mts., Central Europe. Lithos 151: 105-121
Bryon DN, Atherton MP, CheAdle MJ, Hunter RH (1996) Melt movement and occlusion of porosity in crystallizing granitic systems. Mineral Mag 60: 163-171

Bureau H, Keppler H (1999) Complete miscibility between silicate melts and hydrous fluids in the upper mantle: experimental evidence and geochemical implications. Earth Planet Sci Lett 165: 187-196

Cheadle MJ, Elliott MT, McKenzie D (2004) Percolation threshold and permeability of crystallizing igneous rocks: the importance of textural equilibrium. Geology 32: $757-760$

Christiansen EH, Sheridan MF, Burt DM (1986) The geology and geochemistry of Cenozoic topaz rhyolites from the western United States. Geological Society of America Special Papers 205: 1-82

Clarke DB (1992) Granitoid Rocks. Chapman \& Hall, London, pp 1-283

Clarke DB, Bogutyn PA (2003) Oscillatory epitacticgrowth zoning in biotite and muscovite from the Lake Lewis leucogranite, South Mountain Batholith, Nova Scotia, Canada. Canad Mineral 41: 1027-1047

Clemens JD, Droop GTR (1998) Fluids, P-T paths and the fates of anatectic melts in the Earth's crust. Lithos 44: $21-36$

Černý P, London D, Novák M (2012) Granitic pegmatites as reflections of their sources. Elements 8: 289-294

FÖRSTER H-J, ROMER RL (2010) Carboniferous magmatism. In: Linnemann U, Romer RL (eds) Pre-Mesozoic Geology of Saxo-Thuringia - From the Cadomian Active Margin to the Variscan Orogen. Schweizerbart, Stuttgart, pp 287-308

Frezzotti ML (1992) Magmatic immiscibility and fluid phase evolution in the Mount Genis granite (southeastern Sardinia, Italy). Geochim Cosmochim Acta 56: 21-33

Giordano D, Russel JK, Dingwell DB (2008) Viscosity of magmatic liquids: a model. Earth Planet Sci Lett 271: 123-134

Gmelin L (1954) Gmelins Handbuch der anorganischen Chemie, Bor, System-Nummer 13, Ergänzungsband. Verlag Chemie, Weinheim, pp 1-253

Goranson RW (1931) The solubility of water in granitic magmas. Amer J Sci 22: 481-502

GoRBATY YF, BONDARENKO GV (1998) The physical state of supercritical fluids. J Supercrit Fluid 14: 1-8

Hösel G (1994) Das Zinnerz-Lagerstättengebiet Ehrenfriedersdorf/Erzgebirge. Bergbau in Sachsen, Vol. 1, Freistaat Sachsen, Landesamt für Umwelt und Geologie, Freiberg, pp 1-195

JAHNS RH (1982) Internal evolution of pegmatite bodies. In: ČERnÝ P (ed) Granitic Pegmatites in Science and Industry. Mineralogical Association of Canada, Short Course Volume 8: pp 293-327

Johan Z, Strnad L, Johan V (2012) Evolution of the Cínovec (Zinnwald) granite cupola, Czech Republic: 
composition of feldspars and micas, a clue to the origin of W, Sn mineralization. Canad Mineral 50: 1131-1148

Johannes W, Holtz F (1996) Petrogenesis and Experimental Petrology of Granitic Rocks. Springer, Berlin, pp 1-335 KorZhinski DS (1970) Theory of Metasomatic Zoning. Clarendon Press, Oxford, pp 1-162

Kovalenko VI, Kovalenko NI (1976) Ongonites (topazbearing quartz keratophyre) - subvolcanic analogue of rare metal Li-F granites. Nauka, Moscow, pp 1-127 (in Russian)

LETNIKOv FA (2008) Topaz granites in northern Kazakhstan. Petrology 16: 319-334

London D (2008) Pegmatites. Special Publication 10, Canad Mineral, pp 1-347

LONDON D (2009) The origin of primary textures in granitic pegmatites. Canad Mineral 47: 697-724

London D, Morgan VI GB (2012) The pegmatite puzzle. Elements 8: 263-268

LOWENSTERN J B (1995) Applications of silicate-melt inclusions to the study of magmatic volatiles. In: THOMPSON JFH (ed) Magmas, Fluids, and Ore Deposits. Mineralogical Association of Canada, Short Course Volume 23: pp 71-99

LukKari S, Thomas R, HaApala I (2009) Crystallization of the Kymi topaz granite stock within the Wiborg rapakivi granite batholith, Finland: evidence from melt inclusions. Canad Mineral 47: 1359-1374

Marakushev AA, Gramenitskiy YeN (1983) Problem of the origin of pegmatites. Int Geol Rev 25: 1179-1186

McKenzIE D (1985) The extraction of magma from the crust and mantle. Earth Planet Sci Lett 74: 81-91

Mock K, Amato J, Bertmaring J (2012) GeoPixelCounter (Version 1.0) [software]. Retrieved from http://www. math.uaa.alaska.edu/ afkjm/GeoPixelCounter/

MUSTART DA (1972) Phase relations in the peralkaline portion of the system $\mathrm{Na}_{2} \mathrm{O}-\mathrm{Al}_{2} \mathrm{O}_{3}-\mathrm{SiO}_{2}-\mathrm{H}_{2} \mathrm{O}$. Unpublished Ph.D. Thesis, Stanford University, pp 1-187

Naumov VB (1979) Determination of concentration and pressure of volatiles in magmatic melts based on study of inclusions in minerals. Geochimija 7: 997-1007

Naumov VB, Solovova IP, Kovalenko VI, Ryabchikov ID (1987) Composition, concentration of fluid phases, and water content in pantellerite and ongonite melts based on melt inclusion data in minerals. Doklady Akad Nauk SSSR 295: 456-459 (in Russian)

Naumov VB, Kovalenko VI, Yarmolyuk VV, Dorofeeva VA (2000) Volatile components $\left(\mathrm{H}_{2} \mathrm{O}, \mathrm{Cl}, \mathrm{F}, \mathrm{S}\right.$, and $\left.\mathrm{CO}_{2}\right)$ in magmatic melts of various geodynamic environments. Geochem Int 38: 500-509

Oelsner O (1952) Die pegmatitisch-pneumatolytischen Lagerstätten des Erzgebirges mit Ausnahme der Kontaktlagerstätten. Freiberg Forsch H C 9: pp 1-80

Ossenkopf P, Helbig C (1975) Zum geologischen Aufbau der Zinnerzlagerstätte Altenberg und speziell zum Pyknitgestein. Z Angew Geol 21: 57-67
Pistone M, Caricchi L, Ulmer P, Reusser E, Ardia P (2013) Rheology of volatile-bearing crystal mushes: mobilization vs. viscous death. Chem Geol 345: 16-39

Recknagel U (1969) Die Zinnführung der Altenberger Erze in mineralogischer und petrographischer Hinsicht. Unpublished Diploma-Thesis, Bergakademie Freiberg, Freiberg, pp 1-106

REYF FG (1990) Ore forming potential of granites and conditions for their realization. Moscow, Nauka, pp 1-181 (in Russian)

REYF FG (2009) The conditions and mechanisms of the formation of granitic ore magma systems. In: KREMENETSKY AA (eds) Selected Scientific Papers. Institute of Mineralogy, Geochemistry and Crystal Chemistry of Rare Elements, Moscow, pp 1-497 (in Russian)

Rickers K, Thomas R, Heinrich W (2006) The behavior of trace elements during the chemical evolution of the $\mathrm{H}_{2} \mathrm{O}-$, B-, and F-rich granite-pegmatite-hydrothermal system at Ehrenfriedersdorf, Germany: a SXRF study of melt and fluid inclusions. Miner Depos 41: 229-245

Rieder M, Huka M, Kučerová D, Minařík L, Obermajer J, Povondra P (1970) Chemical composition and physical properties of lithium-iron micas from Krušné hory Mts. (Erzgebirge). Contrib Mineral Petrol 27: 131-158

Roedder E (1984) Fluid Inclusions. Mineralogical Society of America Reviews in Mineralogy 12: pp 1-644

SCHNEIDERHÖHN H (1961) Die Pegmatite. Gustav Fischer Verlag, Stuttgart, pp 1-720

SHAw HR (1972) Viscosities of magmatic silicate liquids: an empirical method of prediction. Amer J Sci 272: 870-893

SOWERBy JR, KePPLER H (2002) The effect of fluorine, boron and excess sodium on the critical curve in the albite $-\mathrm{H}_{2} \mathrm{O}$ system. Contrib Mineral Petrol 143: 32-37

Student JJ (2002) Silicate Melt Inclusions in Igneous Petrogenesis. Unpublished Ph.D. Thesis, Blacksburg, Virginia, pp 1-119

Sykes ML, Holloway JR (1987) Evolution of granitic magmas during ascent: A phase equilibrium model. In: Mysen BO (ed) Magmatic Processes: Physicochemical Principles. The Geochemical Society, Special Publication 1: 447-461

Syritso LF (2002) Mesozoic Granitoids of Eastern Transbaikalia and Problems of Rare Metal Ore Formation. St. Petersburg University, St. Petersburg, pp 1-357 (in Russian)

THомаs R (1979) Untersuchungen von Einschlüssen zur thermodynamischen und physikochemischen Charakteristik lagerstättenbildender Lösungen und Prozesse im magmatischen und postmagmatischen Bereich. Unpublished Ph.D. Thesis, Bergakademie Freiberg, pp $1-245+1-83$

Thomas R (1982) Ergebnisse der thermobarogeochemischen Untersuchungen an Flüssigkeitseinschlüssen in Mineralen der postmagmatischen Zinn-Wolfram- 
Mineralisation des Erzgebirges. Freiberg Forsch H C 370: pp 1-85

Tномаs R (1990) Abschätzung der Bildungstemperatur magmatischer Schmelzen. Z geol Wiss 18: 5-14

Thомаs R (1994) Estimation of the viscosity and the water content of silicate melts from melt inclusion data. Eur J Mineral 6: 511-535

Thomas R, Davidson P (2012a) Water in granite and pegmatite-forming melts. Ore Geol Rev 46: 32-46

Thomas R, DAvidson P (2012b) Evidence of a water-rich silica gel state during the formation of a simple pegmatite. Mineral Mag 76: 2785-2801

Thomas R, WeBster JD (1999) Characteristics of berlinite from the Ehrenfriedersdorf pegmatite, Erzgebirge, Germany. Z geol Wiss 27: 443-454

Thomas R, Webster JD (2000) Strong tin enrichment in a pegmatite-forming melt. Miner Depos 35: 570-582

Thomas R, Webster JD, Rhede D (1998) Strong phosphorus enrichment in a pegmatite-forming melt. Acta Univ Carol, Geol 42: 150-164

Thomas R, Webster JD, Heinrich W (2000) Melt inclusions in pegmatite quartz: complete miscibility between silicate melts and hydrous fluids at low pressure. Contrib Mineral Petrol 139: 394-401

Thomas R, Förster H-J, Heinrich W (2003) The behaviour of boron in a peraluminous granite-pegmatite system and associated hydrothermal solutions: a melt and fluid-inclusion study. Contrib Mineral Petrol 144: 457-472

Thomas R, Förster H-J, Rickers K, Webster JD (2005) Formation of extremely F-rich hydrous melt fractions and hydrothermal fluids during differentiation of highly evolved tin-granite magmas: a melt/fluid inclusion study. Contrib Mineral Petrol 148: 582-601

Thomas R, Webster JD, Rhede D, Seifert W, Rickers K, Förster H-J, HeinRich W, Davidson P (2006) The transition from peraluminous to peralkaline granitic melts: evidence from melt inclusions and accessory minerals. Lithos 91: 137-149

Thomas R, Davidson P, Badanina E (2009a) A melt and fluid inclusion assemblage in beryl from pegmatite in the Orlovka amazonite granite, East Transbaikalia, Rus- sia: implications for pegmatite-forming melt systems. Mineral Petrol 96: 129-140

Thomas R, Davidson P, Rhede D, Leh M (2009b) The miarolitic pegmatites from the Königshain: a contribution to understanding the genesis of pegmatites. Contrib Mineral Petrol 157: 505-523

Thomas R, Webster JD, Davidson P (2011a) Be-daughter minerals in fluid and melt inclusions: implications for the enrichment of $\mathrm{Be}$ in granite-pegmatite systems. Contrib Mineral Petrol 161: 483-495

Thomas R, Davison P, Schmidt C (2011b) Extreme alkali bicarbonate- and carbonate-rich fluid inclusions in granite pegmatite from the Precambrian Rønne granite, Bornholm Island, Denmark. Contrib Mineral Petrol 161: 315-329 (and electronic supplemental material)

Thomas R, Davidson P, Badanina E (2012a) Water- and boron-rich melt inclusions in quartz from the Malkhan pegmatite, Transbaikalia, Russia. Minerals 2: 435-458

Thomas R, Davidson P, Beurlen H (2012b) The competing models for the origin and internal evolution of granitic pegmatites in the light of melt and fluid inclusion research. Mineral Petrol 106: 55-73

TischendoRF G (1989) Silicic magmatism and metallogenesis of the Erzgebirge. Publication of the Central Institute for Physics of the Earth Potsdam, Potsdam, 107: 1-316

Tuttle OF, Bowen NL (1958) Origin of granite in the light of experimental studies in the system $\mathrm{NaAlSi}_{3} \mathrm{O}_{8}-$ $\mathrm{KAlSi}_{3} \mathrm{O}_{8}-\mathrm{SiO}_{2}-\mathrm{H}_{2} \mathrm{O}$. The Geological Society of America Memoirs 74: 1-153

Veksler IV, Thomas R, Schmidt C (2002) Experimental evidence of three coexisting immiscible fluids in synthetic granitic pegmatite. Amer Miner 87: 775-779

WeBster JD (ed) (2006) Melt Inclusions in Plutonic Rocks. Mineralogical Association of Canada, Short Course Series 36: 1-237

WeBster JD, Thomas R (2006) Silicate melt inclusions in felsic plutons: a synthesis and review. In WeBster JD (ed) Melt Inclusions in Plutonic Rocks. Mineralogical Association of Canada Short Course Volume 36: pp 165-188

Weinhold G (2002) Die Zinnerz-Lagerstätte Altenberg/ Osterzgebirge. Bergbau in Sachsen, Bd. 9, pp 1-273 